\title{
DEMOGRAPHIC CONSEQUENCES OF THE GREAT PATRIOTIC WAR*
}

\author{
ANATOLY VISHNEVSKY
}

\begin{abstract}
75 years have passed since the beginning of the Great Patriotic War, yet its demographic consequences, felt by Russia throughout all of this time, even now have not been completely overcome. Using general census data starting with the 1939 census, the article traces the fate of the generations who fought (those born between 1890-1926). It is shown that 82\% of women and only 53\% of men registered in the 1939 census survived until 1959. The resulting gender imbalance caused a sharp increase in the proportion of single women as a result of widowhood, and due to a shortage of suitors in the marriage market the share of nonmarital births increased significantly. The war set in motion an oscillating cycle of the annual number of births which continues to this day. A relatively small number of deaths in the postwar decades, due to the fact that a huge number of people killed during the war did not live to a normal age of death, created the illusion of a safe balance of births and deaths in the 1970's-1980's. Cyclical fluctuations in the size of generations induced by the war resulted in a wave-like dynamics of the working population and dependency ratio, complicating the functioning of the labor market and the implementation of economic and social programs, effects which are felt even in our day, for example, in the dynamics of pension contingents.
\end{abstract}

The author discusses the reasons for the huge military losses and suggests that if the war had not been preceded by erroneous decisions of the country's political leaders, these losses could have been much smaller.

Key words: warring generations, war losses, consequences of the war, cost of the victory, gender imbalance.

\section{BACKGROUND: THE 1939 CENSUS}

June 22, 2016 marked 75 years since the start of the most terrible war in the history of Russia. Like other republics of the former USSR, the Russian Federation suffered huge, unprecedented demographic losses in this war. Estimating direct human losses of wartime is not easy. While the war was going on, there was no time for scrupulous recording of casualties (although some recording was of course done). The Soviet leadership was not all that interested in it immediately after the war, either - on the contrary, it tried to avoid a reliable estimate of the losses. This disturbed many, and gave rise to a huge literature. Even today, debate over the estimates has not subsided, and most likely never will. This article is not about the direct evaluation of demographic losses, but about the demographic consequences of the war, which are still being felt. Unlike the extensive literature on military losses, always based on an analysis of unavoidably incomplete data obtained from a variety of sources that often contradict each other, our article uses only official data of state statistics, primarily the results of population censuses , starting with the 1939 census, which recorded all the mobilization contingents of the future "immortal regiment", and ending with the 2010 census, which few veterans lived to see.

AnAtoly Vishnevsky (avishnevsky@hse.ru), NATIONAl ReSEARCH University Higher School Of Economics, RUSSIA.

* THE ORIGINAL ARTICLE IN RUSSIAN WAS PUBliSHEd IN DEMOgRAPHIC REVIEW, 2016, 3(2): 6-42.

URL: HTTPS://DEMREVIEW.HSE.RU/2016--2/190970307.HTML

THE RESULTS OF THE PROJECTS «DEMOGRAPHIC», CARRIED OUT WITHIN THE FRAMEWORK OF THE BASIC RESEARCH PROGRAM AT THE NATIONAL RESEARCH UniverSity Higher SchoOl OF ECONOMICS (HSE) IN 2016-2016, ARE PRESENTED IN THIS WORK. 
The USSR census of 1939 does not have the best reputation. It was carried out in January 1939 to replace the previous 1937 census, declared "defective," as many researchers believe, because it did not show the size of the population that the leadership of the country at that time wanted to see. The task of the new census was to correct this at any cost. Three months after its completion, in March 1939, the $18^{\text {th }}$ Congress of the All-Union Communist Party (Bolsheviks) was held in Moscow. In the report of the Central Committee of the ACP(b) made by Stalin at this congress, the population of the USSR was referred to as if by chance, without mentioning the census. Comparing Russia with England, the speaker noted that "our population is several times larger than that of Great Britain, and hence our requirements are greater: the Soviet Union has a population of 170,000,000, whereas Great Britain has a population of not more than 46,000,000" [Stalin 1978]. It is often assumed that this estimate, given as if merely in passing, was not put in Stalin's report by chance, but to let the statisticians know what result the country's leadership expected from them. And it was just such a result (170,126,000 people) which, 10 days later, on March 21 ${ }^{\text {st }}$, was announced to Stalin and Molotov by the Chairman of the State Planning Committee of the USSR, N.A. Voznesensky, and the head of the Central Statistical Bureau, I.V. Sautin [Volkov 2014: 146-147; Andreev, Darsky, Kharkov 1993: 31; Tolts 2004]. There is another version, according to which the chairman of the State Planning Committee and the head of the Central Statistical Bureau could not have known before the congress what population size Stalin expected from them, and he had no opportunity to inform them other than from the rostrum of the party congress. However, already on March $5^{\text {th }}$ Sautin had informed the country's leadership in a memorandum that the population of the USSR was about 170 million people, so "Stalin announced the figure he was told by the statistical authorities, and not vice versa" [Bashkin, Nazarov, 2014] $]^{1}$.

In any case, the 1939 census gives the last more or less accurate picture of the pre-war population of the USSR, including the population of Russia, which at that time was about $65 \%$ of the population of the USSR. It seems to me that even if the use of the results of this census, taking into account their probable falsification, requires certain reservations, the effect of such falsification on our subsequent calculations can not be significant. If the population of the USSR was artificially overstated by the addition of several million "dead souls" (the number is variously estimated at 1-2 million people for the entire USSR [Zaplin 1989: 180], about 3 million [Volkov 2014: 175], and 1.7 million [Andreev, Darsky, Kharkov 1993: 33], then these additions were distributed among different republics, and the population of Russia is estimated to be overstated by less than half a million people [Andreev, Darsky, Kharkova 1998: 41]. Such overstatement cannot greatly affect the structural proportions nor significantly change the size of individual sex and age groups of the population of a Russia totaling about 110 million people.

From the perspective of demography, 75 years is a short period. If we measure it by the length of a generation - in the demographic sense, this is the average time that passes between the

\footnotetext{
${ }^{1}$ To this one can add, to make the picture fuller, that the three predecessors of I. Sautin as head of the statistical bodies of the USSR - Valerian Obolensky (Osinsky), Ivan Kraval and Ivan Vermenichev - by the time of Sautin's arrival at the job had been shot one after the other, and altogether, out of eight pre-war leaders of the country's main statistical office, five were shot. Sautin survived, but Voznesensky, who signed a memorandum along with him on March 21, 1939, was also executed, albeit later, after the war, during which, as head of the USSR State Planning Committee, he directed the entire Soviet economy, which accomplished the impossible and by the end of the war had ensured a huge superiority over the enemy in the production of weapons.
} 
birth of a child and the moment when he becomes a parent - then 75 years is just about three cycles of such transformations. And for all these 75 years we have felt, perhaps without realizing it, the unhealed wounds of the war.

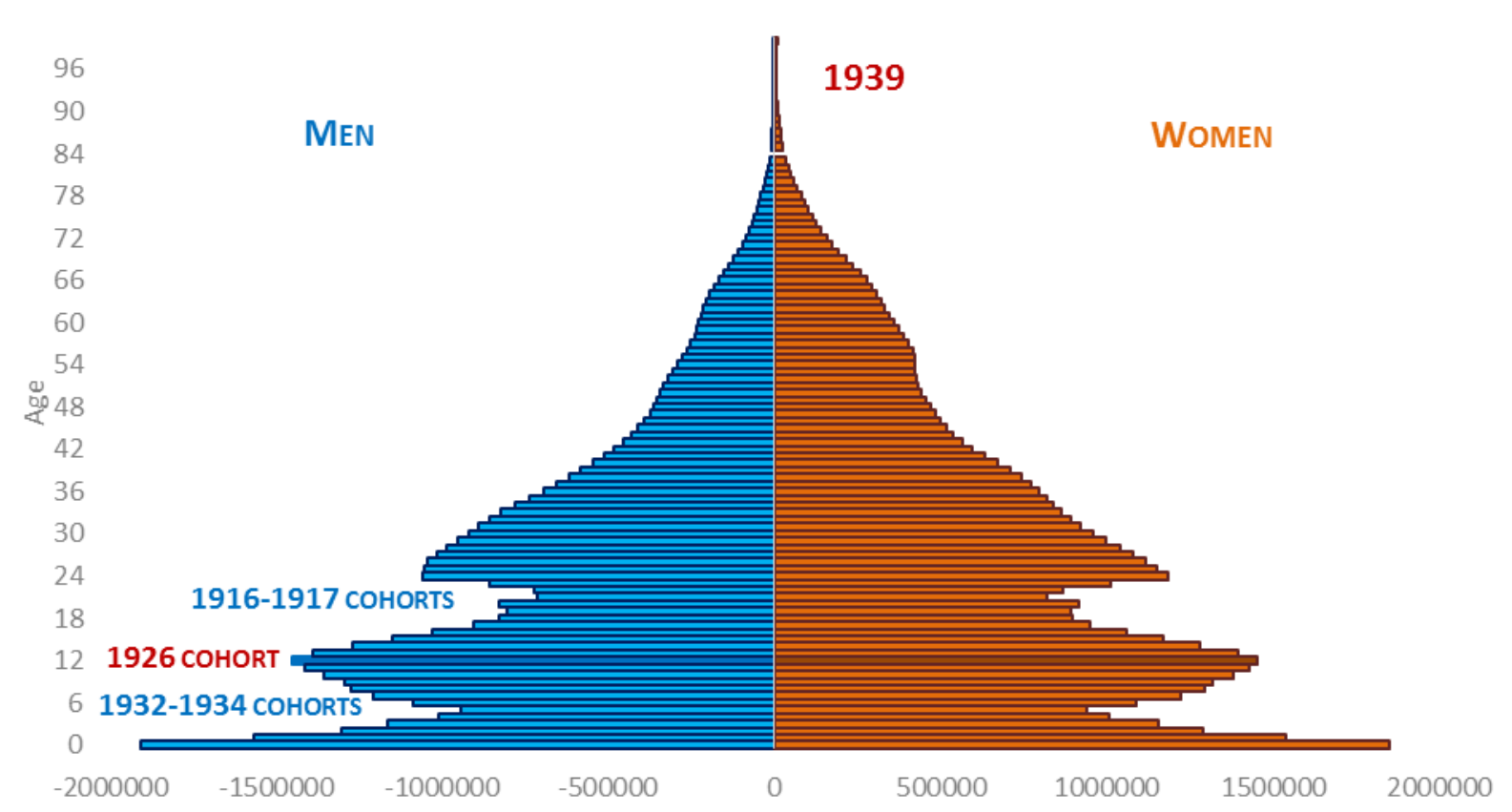

Figure 1. Russia population pyramid according to the population census of January 17, 1939, persons

The 1939 census gives the last more or less accurate picture of the pre-war population of Russia (as of the whole of the USSR, but this article only deals with Russia). The main part of the population that directly fought in 1941-1945 were male generations born between 1890 and 1926 . They suffered the greatest losses. Of course, the age boundaries between generations participating and not participating in the fighting are somewhat blurred. Furthermore, women also took part in the war, and losses were incurred by the civilian population, too, so it is impossible to reduce everything only to the losses of these male cohorts. Still, it is men who bore the main impact.

Figure 1 shows the age pyramid of the population of Russia according to the 1939 census. In its lower part we see a deep depression - the terrible trace of the famine of 1932-1933, but this is not relevant to the topic of our article. We are interested in the part of the pyramid that covers the generations of Russians born between 1890 and 1926. For simplicity, we will continue to refer to these generations as "the warring generations". In 1939, they accounted for the majority of the population of Russia - 58\% of all men and almost $57 \%$ of all women (Table 1).

Table 1. The population of Russia according to the 1939 census

\begin{tabular}{|c|c|c|c|}
\hline & Men & Women & Both sexes \\
\hline All generations, million people & 51.1 & 57.3 & 108.4 \\
\hline Including generations of $1890-1926$ & & & - \\
\hline Million persons & 29.6 & 32.6 & 62.2 \\
\hline as $\%$ of the whole population & 58.0 & 56.9 & 57.4 \\
\hline
\end{tabular}

The warring generations were, in turn, heterogeneous in terms of their history, which left its imprint on the size and structure of the population. In January 1939, when the last pre-war census took place, representatives of these generations were from 12 to 48 years old. Some of them 
were born during the ordeal of the First World War and the Civil War (1915-1921); the low fertility of these years left a deep hole in the population pyramid. In the 6 years before the First World War (from 1909 to 1914), 27.9 million children were born in Russia. In the 6 years after the war (from 1923 to 1928), when the storms of the Civil War had died down, 27.4 million were born. But between 1916 and 1921 - the same length of time - the figure was only 20 million (1915 and 1922 were transitional years from peace to war and from war to peace).

For most members of the warring generations this was not their first war. If we assume, with of course a certain degree of conditionality, that only men aged 17 and older could participate in the Civil War, and that this war ended in 1921, then the more or less participating generations were those born before 1905. In 1939, these generations accounted for more than $27 \%$ of men and almost $30 \%$ of women of the warring generations. By that time the gender balance had already been significantly disrupted: there were only 83 men per 100 women (Table 2).

Table 2. Warring generations according to the 1939 census

\begin{tabular}{|c|c|c|c|c|c|c|c|c|}
\hline \multirow[b]{3}{*}{ Generations } & \multicolumn{6}{|c|}{ Generation size } & \multirow{3}{*}{$\begin{array}{l}\text { Excess } \\
\text { of } \\
\text { females, } \\
\text { millions }\end{array}$} & \multirow{3}{*}{$\begin{array}{c}\text { Sex ratio } \\
\text { (men per } \\
100 \\
\text { women) }\end{array}$} \\
\hline & \multicolumn{3}{|c|}{ Million persons } & \multicolumn{3}{|c|}{$\%$} & & \\
\hline & $\sum_{\Sigma}^{\tilde{\Xi}}$ & $\begin{array}{l}\bar{\Xi} \\
\text { है } \\
3\end{array}$ & 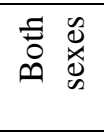 & $\sum_{\Sigma}^{\bar{E}}$ & 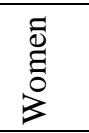 & 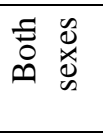 & & \\
\hline $\begin{array}{r}1890-1926 \\
\text { including: }\end{array}$ & 29.6 & 32.6 & 62.2 & 100.0 & 100.0 & 100.0 & 2.9 & 91 \\
\hline $1890-1904$ & 8.1 & 9.7 & 17.7 & 27.2 & 29.7 & 28.5 & 1.6 & 83 \\
\hline $1905-1922$ & 16.3 & 17.6 & 33.9 & 55.1 & 54.1 & 54.5 & 1.3 & 93 \\
\hline $1923-1926$ & 5.3 & 5.3 & 10.6 & 17.8 & 16.3 & 17.0 & 0.0 & 99 \\
\hline
\end{tabular}

The most numerous component of the warring generations were those born in 1905-1922, who had not yet taken part in any war by the time of the 1939 census. Between 16 and 33 years old at the beginning of 1939 (hence, between 18 and 35 in 1941), they make up about 55\% of the warring generations. They include also the small generations of 1916-1921, 17 to 22 years old at the time of the census, for a total of only 4.8 million men (1.3 million fewer than men aged 2429). In two years, when the war began, these small generations would reach the age of 19 to 24 years. For the whole group of generations born between 1905 and 1922 there were not 83 men per 100 women, as in the previous group, but 93 - a much better sex ratio, yet still a perturbed one, primarily due to the generations born in 1915-1917. The cause of this perturbation is not clear.

Finally, another group - adolescents 12-15 years old, born in 1923-1926. Their sex ratio is not perturbed, but in 1941 they would be 14-17 years old, and in 1944, 17-20 years. They would still have to fight, although not in the most difficult period of the war.

\section{THE DEATH PATH OF THE IMMORTAL REGIMENT}

As is known, Stalin did not allow a census or at least a simplified population count of the USSR after the war, meaning this very important information about the war's demographic results was irretrievably lost. However, the consequences of demographic shocks take a long time to fade; the population pyramid retains their memory for many decades to come. The first post-war census, although conducted only in 1959, 20 years after the previous census of 1939 and almost 15 years after the end of the war, showed very much of what Stalin wanted to conceal, and all subsequent 
censuses, including the census of 2010 , allow us to see how the warring generations passed.

In Figure 2 and Table 3, we see how their demographic fate developed up to 1979. In 1939 (Figure 1), the right and left parts of the population pyramid were also not completely symmetrical, but their asymmetry still did not stand out at first glance. 20 years later, the contour of the pyramid narrowed from both sides, but the asymmetry became plain as day. And it continued to grow. 20 more years later, by 1979, it had become even more pronounced: the male part of the warring generations was dying faster than the female one.

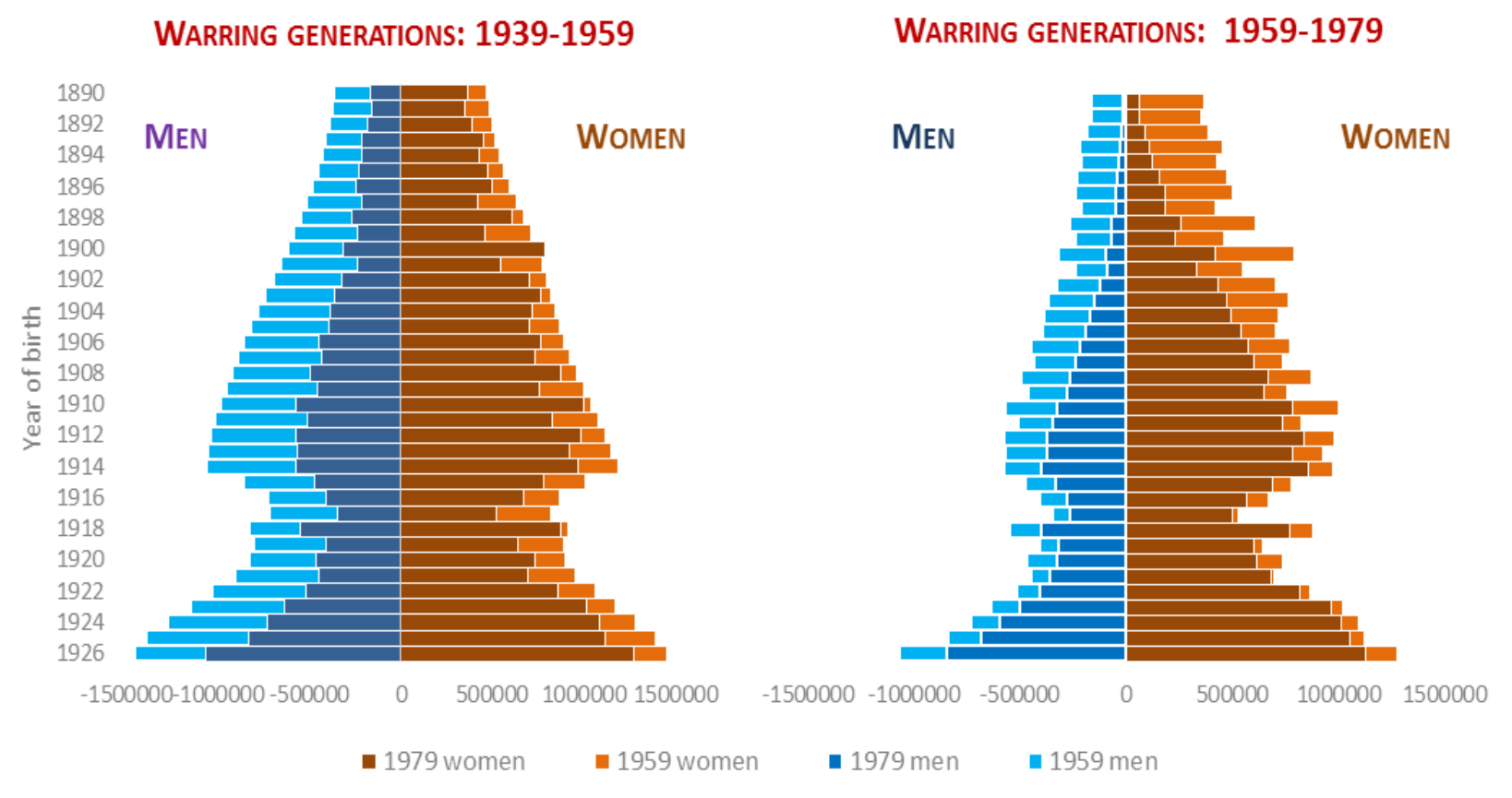

Figure 2. Population pyramids of the warring generations in 1939-1959 and in 1959-1979 according to population censuses of 1939, 1959 and 1979, persons

Table 3. Warring generations in 1939, 1959 and 1979

\begin{tabular}{|c|c|c|c|}
\hline & Men & Women & $\begin{array}{l}\text { Both } \\
\text { sexes }\end{array}$ \\
\hline \multicolumn{4}{|l|}{ Total size, million } \\
\hline 1939 & 29.6 & 32.6 & 62.2 \\
\hline 1959 & 15.7 & 26.8 & 42.5 \\
\hline 1979 & 9.4 & 20.0 & 29.4 \\
\hline \multicolumn{4}{|c|}{ Decrease, million for period } \\
\hline 1939-1959 & 13.9 & 5.8 & 19.7 \\
\hline 1959-1979 & 6.3 & 6.8 & 13.1 \\
\hline 1939-1979 & 20.3 & 12.6 & 32.8 \\
\hline \multicolumn{4}{|c|}{ Decrease, $\%$ of reference year } \\
\hline for $1939-1959$ & 47.1 & 17.8 & 31.7 \\
\hline for $1959-1979$ & 40.2 & 25.3 & 30.8 \\
\hline for $1939-1979$ & 68.4 & 38.6 & 52.8 \\
\hline \multicolumn{4}{|c|}{ Still alive from the total number recorded by the 1939 census, $\%$} \\
\hline by 1959 & 52.9 & 82.2 & 68.3 \\
\hline by 1979 & 31.6 & 61.4 & 47.2 \\
\hline
\end{tabular}

Between the censuses of 1939 and 1959 the number of people in the warring generations decreased by 19.7 million, while the loss of men exceeded that of women by 8.2 million (Table 3). Although this difference cannot, of course, be automatically identified with losses at the front, 
affecting mainly men, it seems to be not far from them, because wartime hardships not directly related to military action, as well as the difficulties of post-war life, were equally experienced by both men and women.

For the next 20 years (between the censuses of 1959 and 1979), the losses of the warring generations from mortality were much smaller and did not differ so much by sex. In absolute terms, the decrease in women was even greater than that of men, but this is explained by their much higher initial total number in 1959. In relative terms, the male part of the warring generations was reduced by more than $40 \%$, while the female part was reduced by only a quarter.

By the time of the 1979 census, the original size of the warring generations recorded in the 1939 census had shrunk by more than half - but this is only for both sexes together. While the number of women declined by less than $40 \%$, less than a third of the men from the warring generations remained (Table 3).

A little more than 20 years later, in 2002, the first census of post-Soviet Russia was conducted. It showed that by this time approximately one-tenth of the initial number of the warring generations (62.2 million in 1939) remained: 1.6 million men and 5 million women (Figure 3). It was at about this time that Victory Day celebrations of the war in which they fought became particularly loud and triumphant.

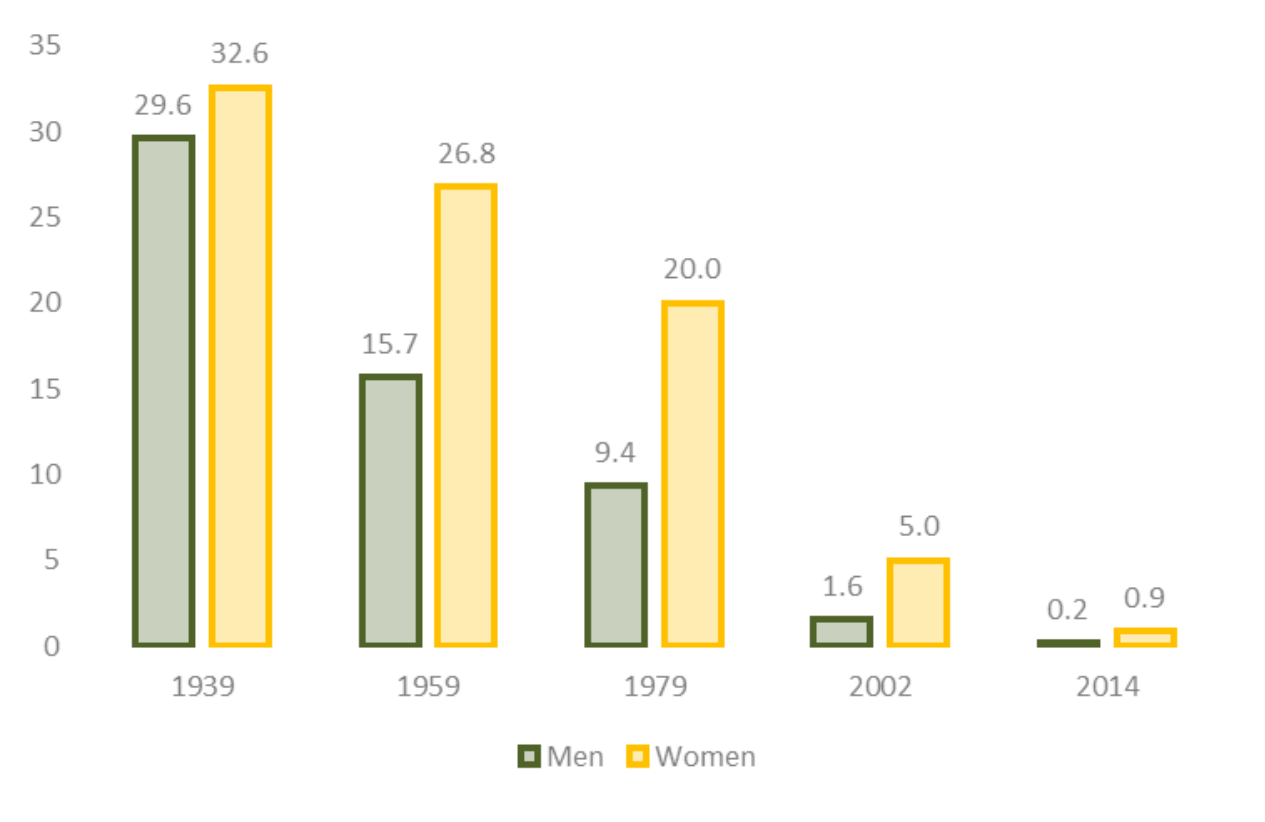

Figure 3. The passing of the warring generations, in millions

\section{THE TRACES OF THE WAR ON THE POPULATION PYRAMID}

The death of a huge number of people belonging to many generations greatly deforms the entire age pyramid. But to this are also added deformations caused by a sharp decline in fertility during the war years. The deformations caused by war not only persist for a long time, shifting over time to the top of the pyramid, but generate new deformations in its lower part, "echoes" of war that can be heard for many decades. The war launched a cycle of fluctuations in the number of cohorts one after the other, giving a cyclical, wave-like character to the entire demographic development 
of Russia. This is clearly seen on the graphs, and it very much affects the real life of many tens of millions of people - their private life and the economic and social life of the whole country.
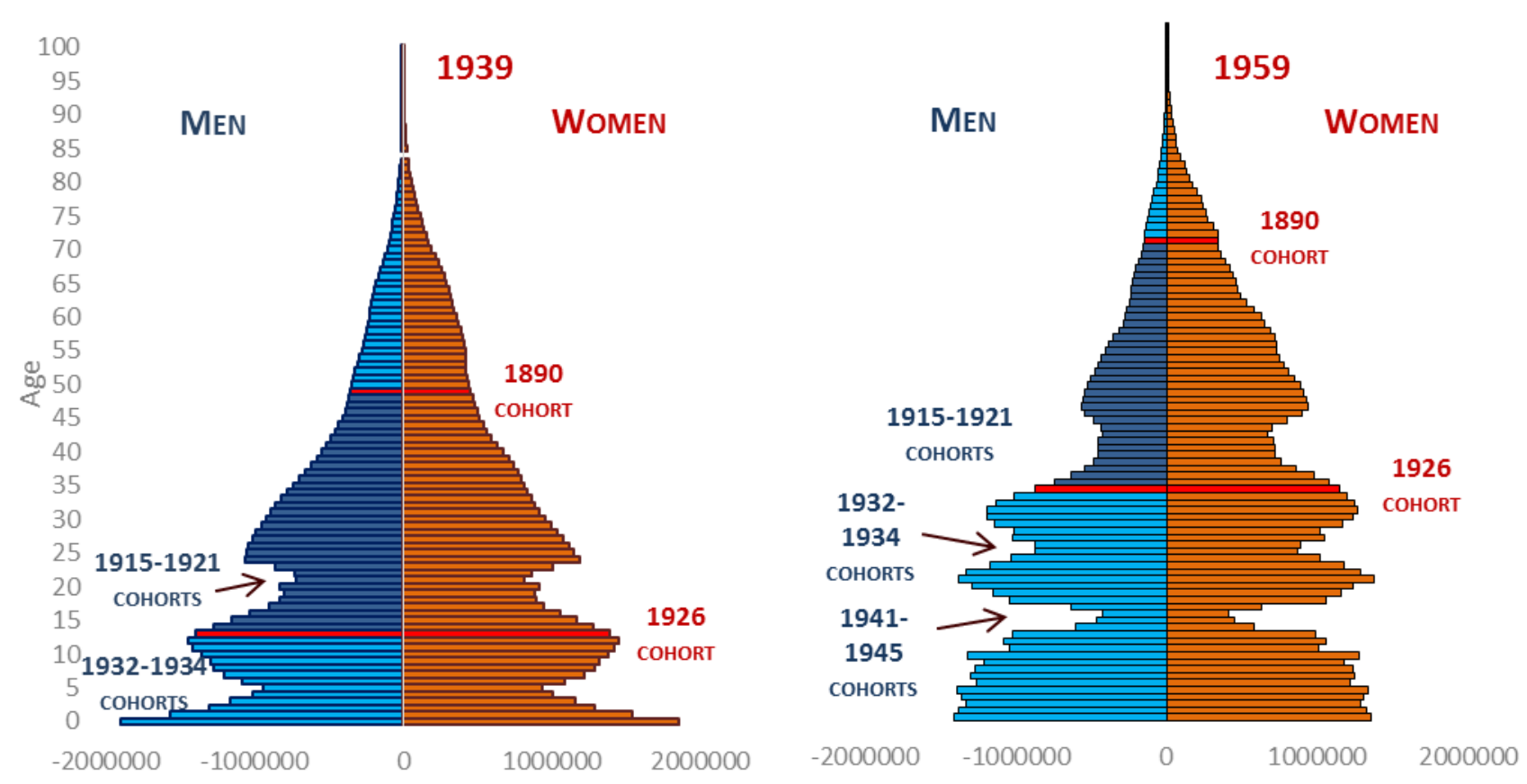

Figure 4. Russia population pyramids in 1939 and 1959, persons

We have already seen a sharply increased asymmetry of the male and female parts of the pyramid in the warring generations, as well as an upward moving but still persisting depression the consequence of the fall in fertility and the increase in infant mortality in 1915-1921 and in 1932-1934. A comparison of the pyramids of 1939 and 1959 (Figure 4) shows yet another new huge depression: a trace of the extremely low fertility of 1941-1945.

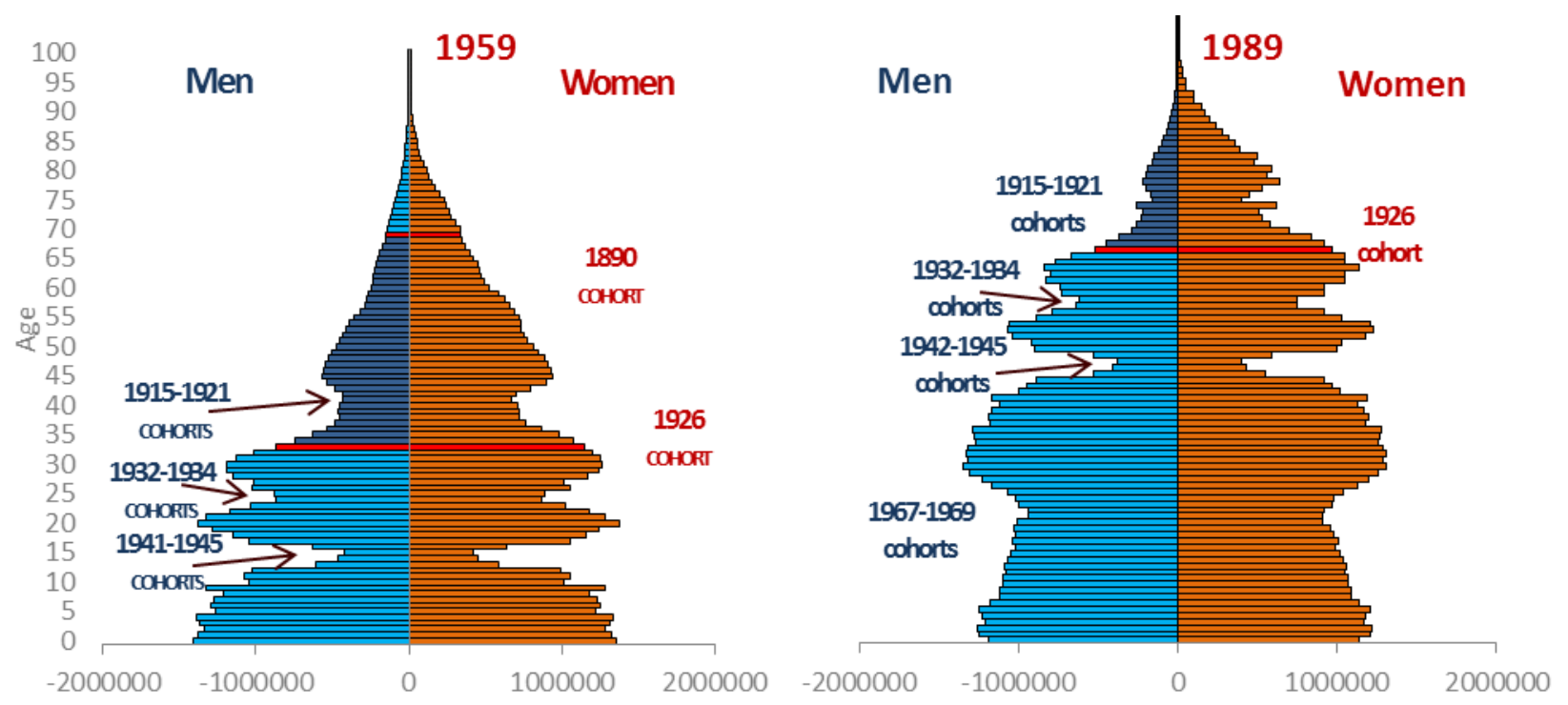

Figure 5. Russia population pyramids in 1959 and 1989, persons

If we now move another thirty years ahead and compare the 1959 pyramid with the 1989 pyramid built on the basis of the last Soviet population census (Figure 5), we will see a clear improvement in gender balance in the lower part of the pyramid, while in the upper part of the 
pyramid, where the warring generations are now concentrated, a pronounced gender asymmetry remains. But what attracts attention is the appearance in the lower part of the age pyramid of 1989 of a new hollow - the echo of the fall in fertility in the war years. A quarter of a century after the war, the children of the war years became parents themselves, but as there were few of them, the number of their children was also small - the deepest fall was in 1967-1969, 25 years after 19421945.

Finally, we compare the population pyramid of 1989 with the pyramid of 2010, built according to the most recent census data at the time (Figure 6). The red line of the birth year 1926, separating the generations of those who fought from those who did not, is approaching the top of the pyramid; in 2010, those who were born in 1926 were 84 years old. But the trace of the war can be spied in a new hollow in the lower part of the pyramid - the next echo of the war. A quarter of a century after the first post-war decline in the number of children born to children of the war, their children became parents, and, as we have seen, they too were relatively few, so that a new fall in the number of births was to be expected. Judging by the pyramid of 1989, it had already begun to take shape in the late 80's. But, apparently, the fall in the number of births in the 1990s, which was inevitable in any case, intensified under the impact of socio-political, economic and even demographic changes taking place at that time, and was deeper than one might expect.

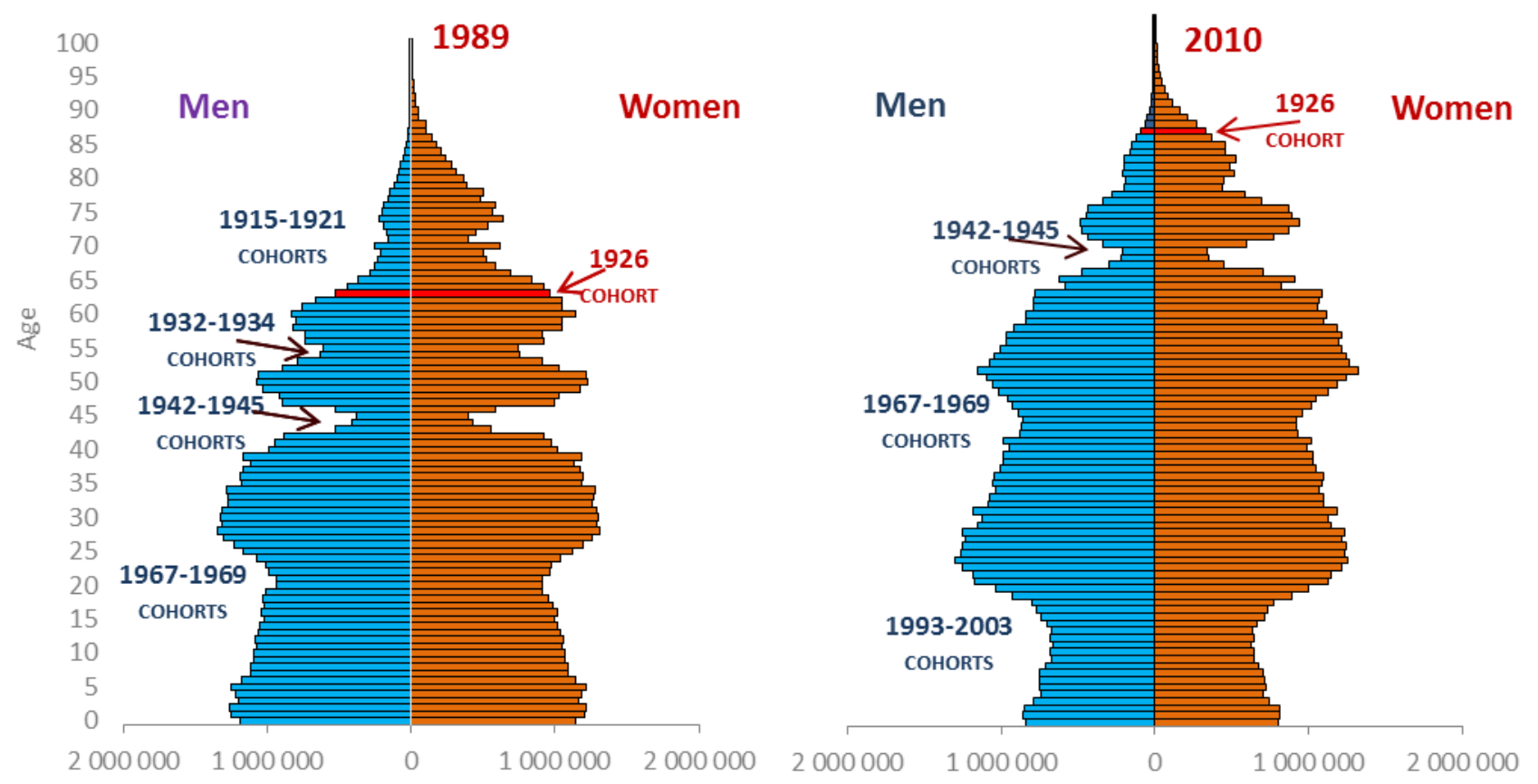

Figure 6. Russia population pyramids in 1989 and 2010, persons

\section{GENDER ASYMMETRY}

Throughout almost the whole of the twentieth century, Russia lived in conditions of an unnatural gender asymmetry that arose after the First World War and the Civil War and increased sharply after the Second World War.

A significant preponderance of women is characteristic of all countries that fought in the war, but in Russia it is especially large even in comparison with Germany, which also suffered 
huge losses in the First, and especially, of course, Second World War. It is not surprising that in the post-war population pyramids of both countries there is much in common (Figure 7).

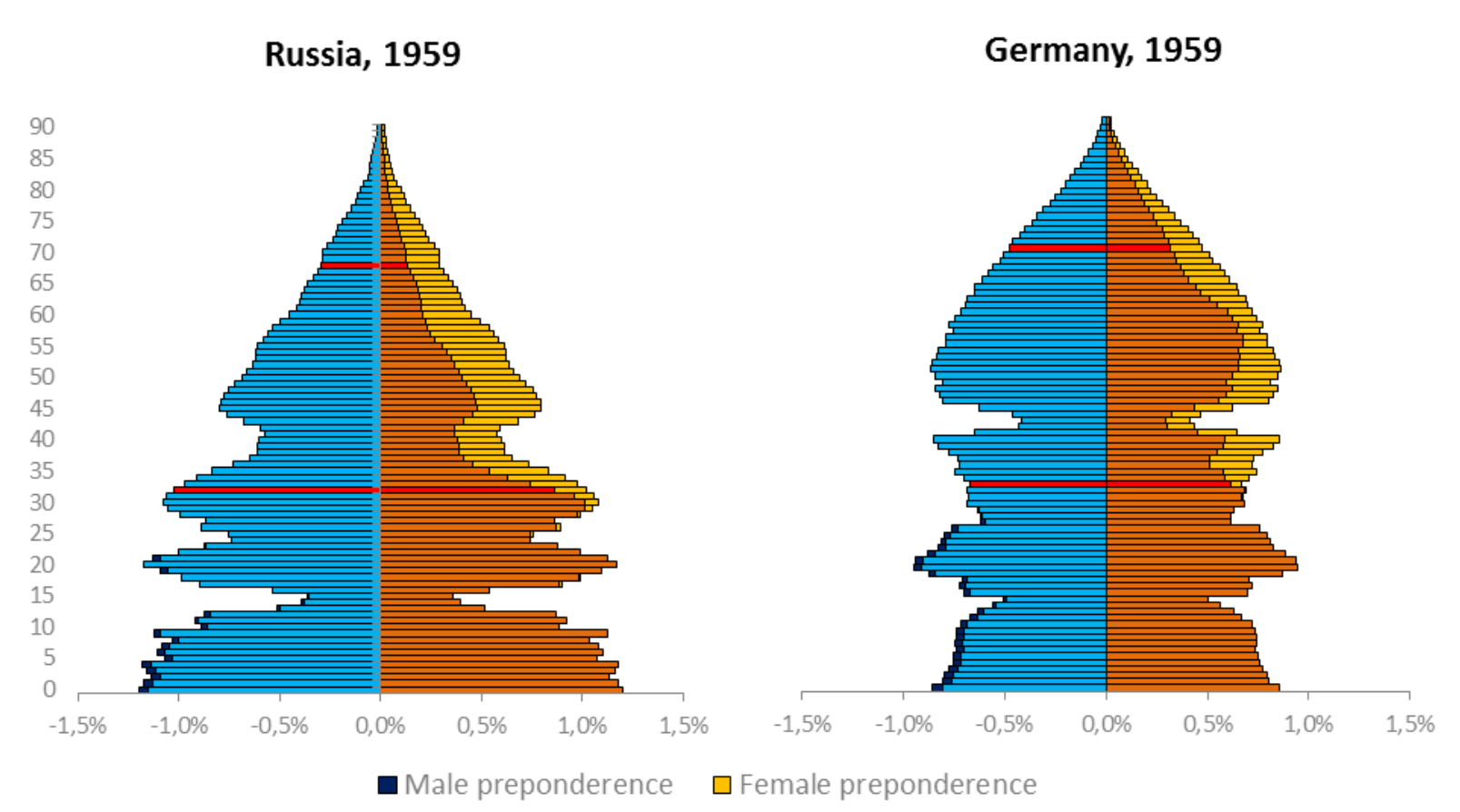

Figure 7. Russia and Germany. Population pyramids in 1959, percent of population

Source for Germany: [Statistisches Bundesamt 2016].

Nevertheless, upon closer examination it turns out that the female preponderance in the warring generations in Russia is incomparably greater than in Germany. It is especially great in the generations that fought in the wars of the second decade of the twentieth century (those born approximately before 1905), which is understandable, because unlike Germany, Russia suffered losses not only in the First World War, but also in the Civil War. Nevertheless, it is also significant in younger generations (Figures 8 and 9), which speaks also of the more significant losses of Russia in the Second World War.

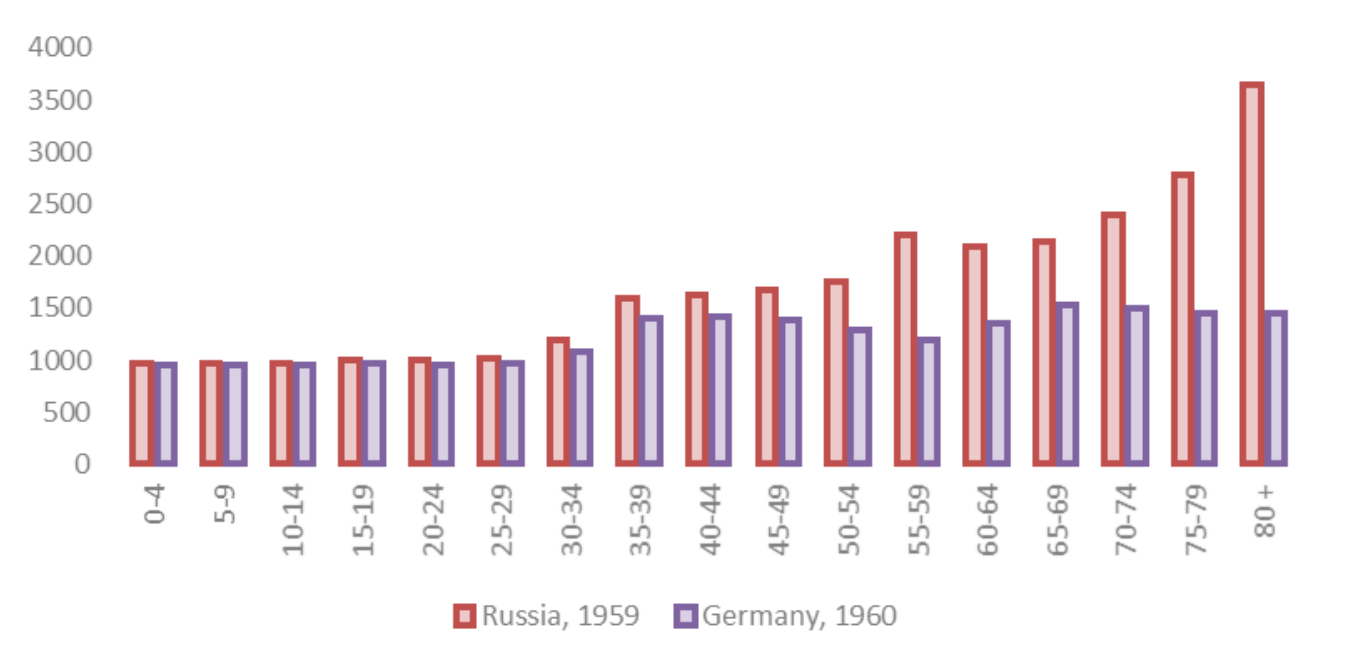

Figure 8. The number of women per 1000 men in Russia and Germany in 1959

Source for Germany: [Statistisches Bundesamt 2016]. 
Military losses are not the only source of disturbance of gender balance in the population. A second cause is the higher mortality of men during the postwar period, which in Russia greatly exceeds female mortality. Yet, for at least five decades after the outbreak of war, military losses were the main source of gender imbalance. As the warring generations began to age, the imbalance of the sexes also shifted to the upper part of the population pyramid; in the non-warring generations the sex ratio was much more favorable.

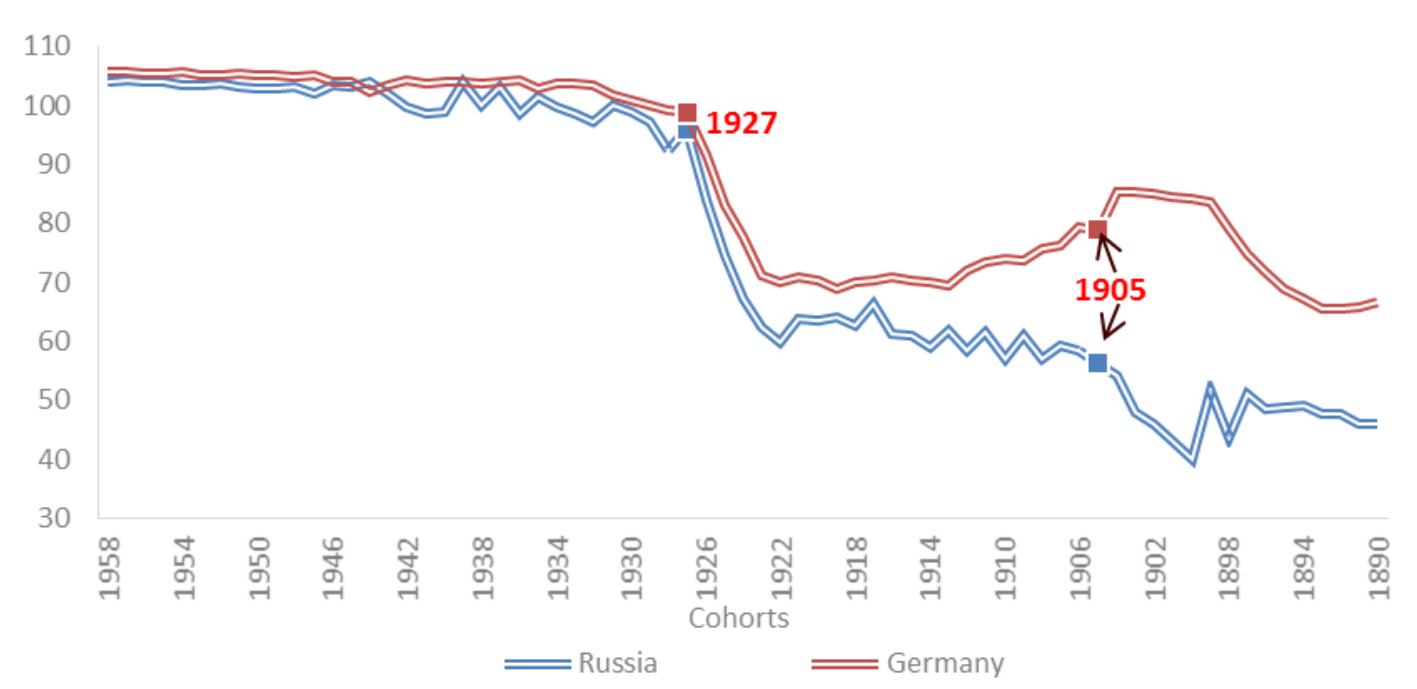

Figure 9. The number of women per $\mathbf{1 0 0 0}$ men in warring and non-warring generations in Russia and Germany in 1959

Source for Germany: [Statistisches Bundesamt 2016].

According to the 1959 census, the female preponderance is noticeable starting from the age group of 30-34, in 1970 from the age 40-44 group, in 1979 from the group aged 50-54 years, etc. (Figure 10).

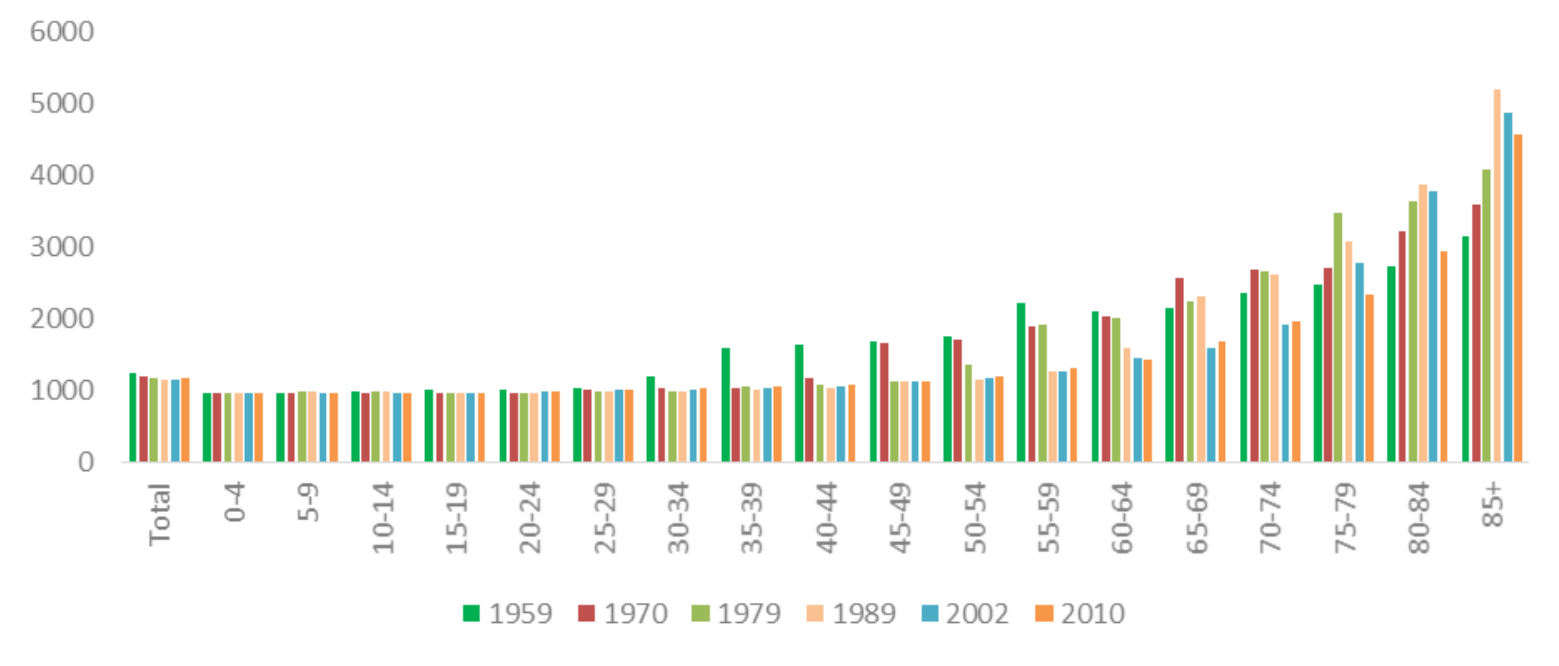

Figure 10. The sex ratio by age groups according to the Russian postwar censuses, women per 1000 men

Even in 1989, the main contribution to the overall female preponderance in the population of Russia was made by the warring generations - due to huge military losses, but also at the 
expense of higher male mortality in the post-war period. As these generations became less numerous, their contribution to the female preponderance in the entire population also declined, and as a result this preponderance diminished. The change in the situation was registered only by the 2002 census: the contribution of the warring generations was significantly reduced, and yet the female preponderance increased (Figure 11). This is no longer connected with the consequences of the war, but is due to a significant excess of male mortality over female. Before 1992, despite the higher male mortality, the absolute number of male deaths was less than that of females - a consequence of the smaller size of the male population. Starting in 1992, the situation was reversed: even despite the smaller size of the male population, more male deaths were recorded each year. Over 10 years, from 1982 to 1991, the number of female deaths exceeded that of male deaths by 597,900. Over the 10 years from 1992 to 2001, on the contrary, 927,100 more men died than women, and in the next decade, from 2002 to 2011, 1,292,700 more. It is clear that this could not but affect the sex-ratio in Russia. Of great importance also is demographic aging, since it results in an increase of the proportion of older age groups with a less favorable sex ratio. But all this applies to the very last decades, while most of the twentieth century was marked by a gender imbalance due to military losses.

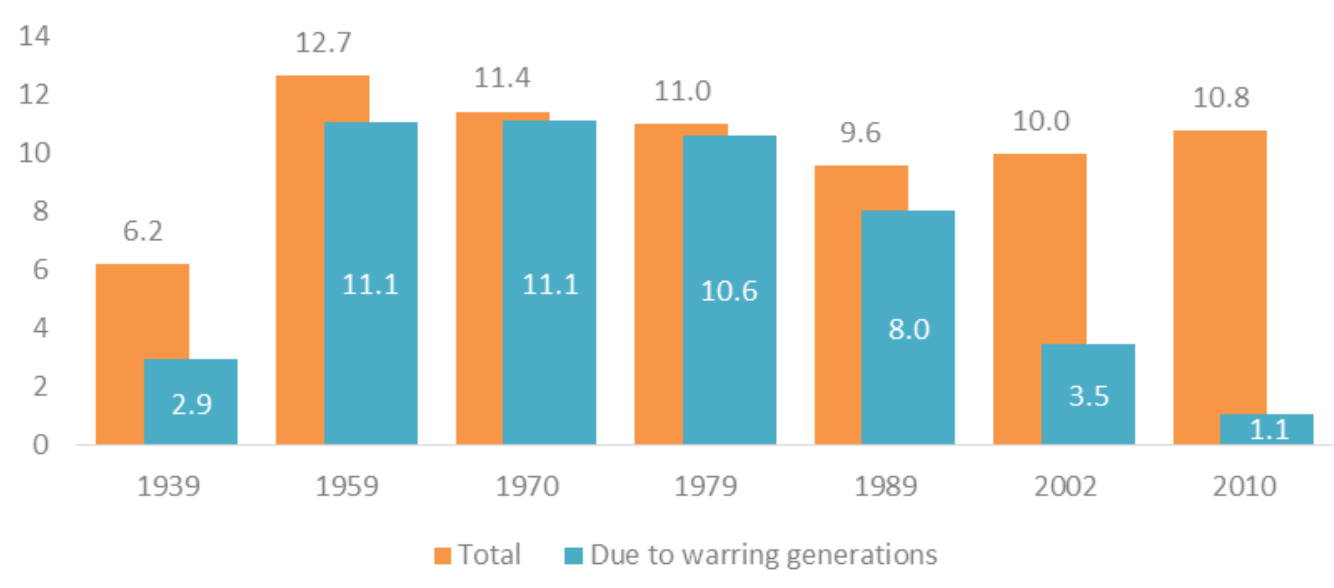

\section{Figure 11. Female preponderance in Russia according to population censuses of 1939-2010, millions}

\section{THE WAR AND FAMILY}

The unprecedented losses among the male population deprived many women of potential marital partners, which led to a significant increase in the proportion of women who never married. The matrimonial fate of women of the warring generations, beginning with the generations born in 1900 , can be assessed with the help of retrospective estimates made by S. Zakharov on the basis of the data of the micro-census of 1994, taking into account not only officially registered, but also actual marriages (Figure 12).

While $95 \%-96 \%$ of the generations of women who did not participate in the war and who reached the age of 50 years or older by 1994 - when, that is, they were basically already beyond the age of a first marriage - were married during their lifetime, for women of the warring generations the corresponding figure is $93.5 \%$ or less, and this proportion falls sharply among the 
youngest of the warring generations, for whom before 1941 the process of forming married couples had not yet gained momentum.

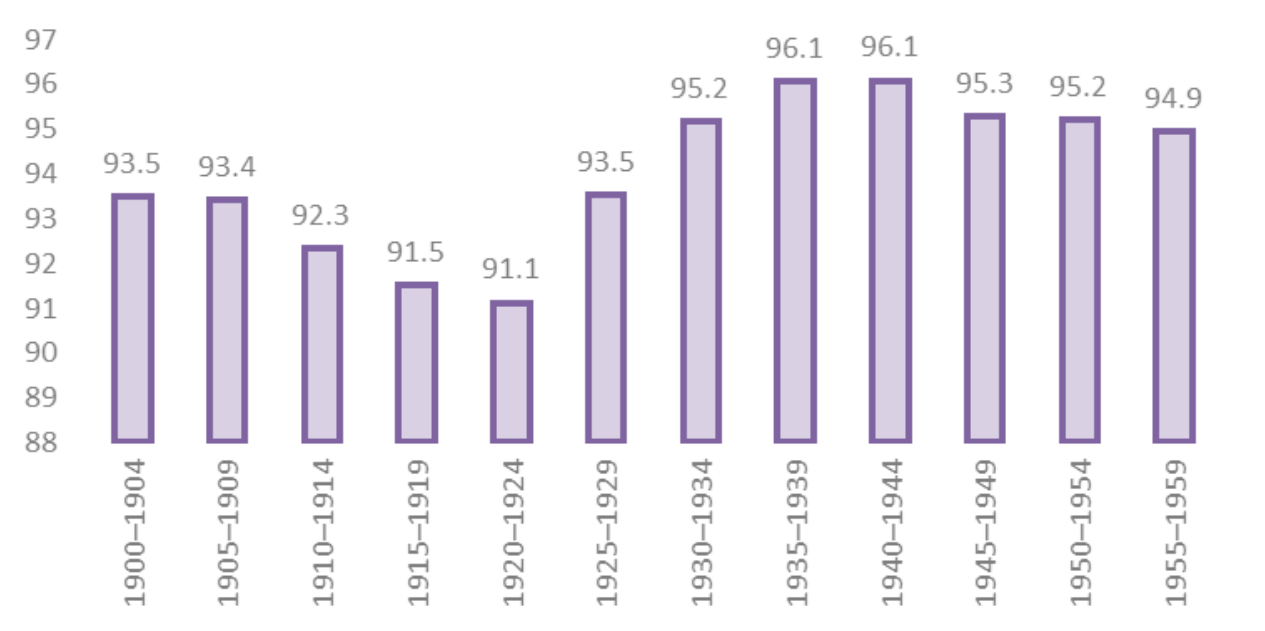

Figure 12. The proportion of ever married women in the warring and non-warring generations, $\%$

Source: [Demograficheskaya modernizatsiya... 2006: 113-114].

But the effect of the war on the marital status of the population is by no means limited to women's difficulties in finding a marriage partner due to a shortage of suitors. The influence is much deeper and more varied. The war destabilized the marital and family status composition of the population, destroyed many marriages often barely begun, and increased competition in the marriage market, which had as a consequence an increase in the number of divorces. It is hardly possible to fully assess all these consequences today.

The country was left with a huge number of widows, but just how many was unknown, and the 1959 census is of no help in estimating the number. Although international standards for conducting censuses have always made provision for questions distinguishing four categories of marital status, including widows, and such questions were asked in Russia even during the first general census of 1897 and the first All-Union census of 1926, the statistics of Stalin's time considered such questions not worthy of attention, and, starting with the 1937 census and ending with that of 1970, Soviet censuses (hence the one in 1959) made it possible to distinguish between only two categories: married and unmarried at the time of the census. Accordingly, there was no information on the number of widows in them; questions concerning all marital statuses first appeared again only in the program of the Soviet census of 1979 [Vishnevsky, Zakharov 2010: 13].

There was also no information on the number of post-war orphans left without one or both parents, as well as on the number of disabled veterans, which was huge. Widows, orphans and disabled veterans have always been present in the propaganda rhetoric, but no one knew how many there were, and no one tried to find out. Probably, some statistics nonetheless existed in social security agencies that paid benefits to widows and children of those who died at the front and to war invalids, but they were never made public and were not present in the public discourse. In the scientific literature one can find only the most general mentions like "in the generations of women 
who in 1941 were 17-25 years old and who suffered the most during the war ... there were a lot of widows and unmarried women" [Polyakov, Zhiromskaya, Aralovets 2004], but no more than that.

In fact, the 1959 census indicated only a very low percentage of married women among those between the ages of 40 and 59 in comparison with previous censuses (i.e. those who were between 20 and 39 years old in 1939; figure 13 ), and this, of course, is the result of the joint effect of widowhood, divorce and not getting married.

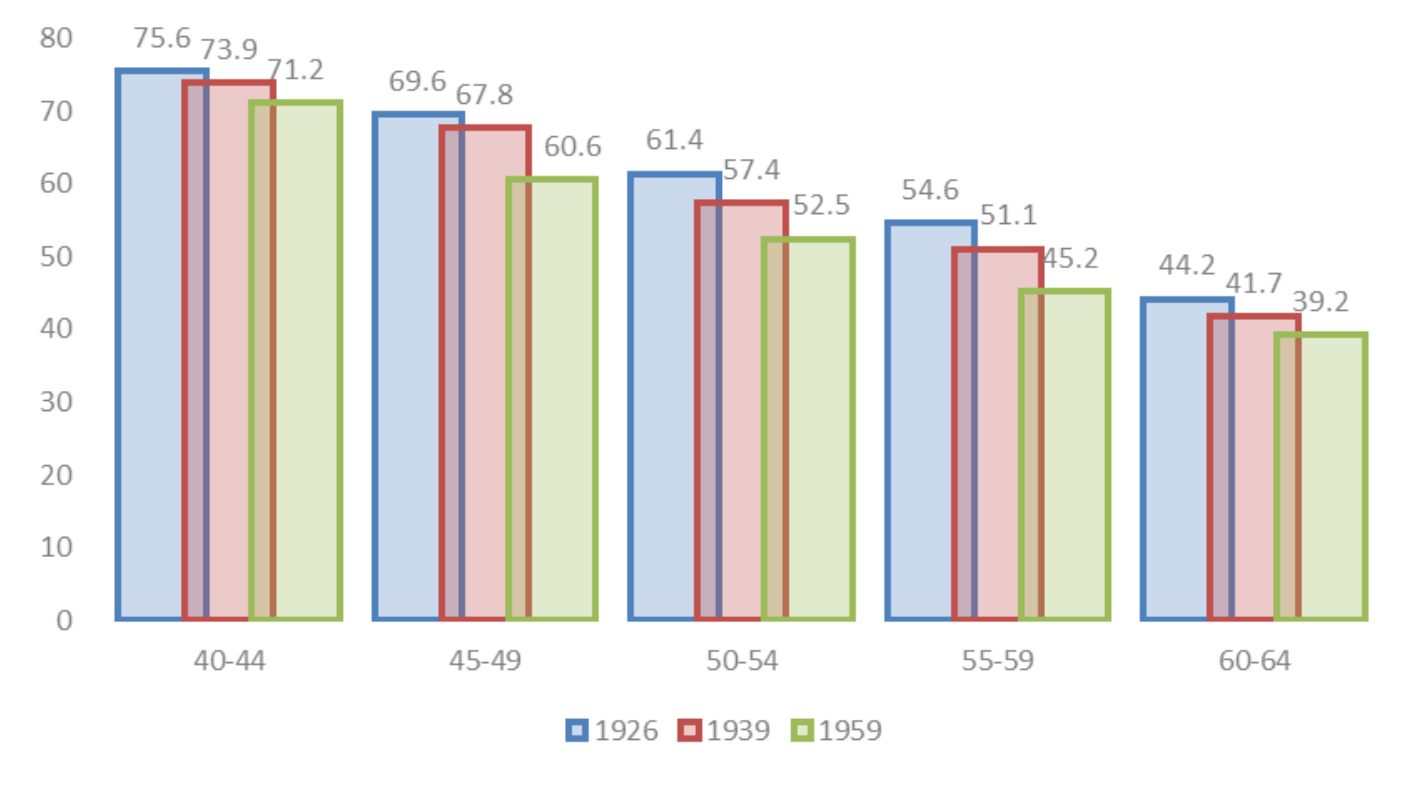

Figure 13. The number of married women per 100 women of the corresponding age group
according to the censuses of 1926,1939 and 1959

To a very large extent, all these factors are a consequence of the postwar deformations of the marriage market and the competition that arose due to the shortage of men. "The widowhood of many women who lost their husbands in the war, because of the gender imbalance, lasts for all the rest of their life ... In conditions of a significant numerical preponderance of women, the strength of marriages is significantly weakened, and the increase in the number of divorces initiated by men reduces the duration of marriage. In the presence of gender imbalance there is a process of spontaneous redistribution of marriage partners, and not only by age but also by marital status. This redistribution is made through the increase in marriages of women with their peers and younger men, whose generations have not been affected by the war, as well as with divorced and widowed men" [Ilyina 1977: 55].

The state tried to counteract the inevitable processes in the given situation by the only means available to it - the tightening of legislation regarding marriage and family. On July 8, 1944, less than a year before the end of the war, a Decree of the Presidium of the Supreme Soviet of the USSR was adopted which sharply altered the previously relatively liberal Soviet legal norms concerning marriage and family. The decree was beautifully called: "On increasing state aid to pregnant women, mothers with many children and single mothers, strengthening the protection of motherhood and childhood, and on establishing the honorary title of Mother Heroine, the Order of Maternal Glory and the Motherhood Medal" [Decree of 1944]. 
Nothing in the title of the decree said anything about the contents of section V, "On Amendments to the Law on Marriage, Family and Guardianship." Yet it was this section that set the condition that "only a registered marriage engenders the rights and duties of spouses" and abolished the "existing right of the mother to appeal to the court for the establishment of paternity and the awarding of alimony for the support of a child born of a person with whom she is not in a registered marriage." It stipulated that when registering the birth of a child born to a mother not in a registered marriage, the child be given the mother's surname and the patronymic chosen by the mother. A rule was introduced requiring that a registered marriage be recorded in one's internal passport, and divorce procedure was made much more complicated. The decree also reinforced the existing norm of authorizing "the prosecution authorities, in accordance with the current criminal legislation, to prosecute those guilty of illegally conducting abortions, or compelling women to have an abortion."

The innovations contained in the decree were motivated by the fact that "taking care of children and mothers and strengthening the family has always been one of the most important tasks of the Soviet state", but in fact the state unequivocally made it clear to women who were left without men that this was their problem. In a sense, the decree played the role of a screen making all phenomena the state wanted concealed inaccessible to state statistics and hidden from public opinion. The number of registered divorces did in fact decline, but this does not mean that marriages ceased to disintegrate without registration. About the number of actual divorces driven into the underground nothing was known, but when in 1965 the procedure of divorce was simplified, the number of divorces in one year increased 1.8 times (from 360 to 646 thousand) [Central Statistical Board of the USSR 1975: 150]. The difficulty of the divorce procedure made remarriages harder, but this only means that a significant part of them ceased to be recorded by statistics, so their number is also unknown.

No decrees could change the post-war demographic realities. A huge number of women were doomed to loneliness, and children to fatherlessness. Non-marital children became common after the war, and in the USSR the number of single mothers increased sharply. According to available estimates, in 1945 there were 281,700 such mothers, and in 1957 - 3,312,000 [Kharchev 1979: 168-169]. About a quarter of all births in 1945 were non-marital, and even 10 years later almost $17 \%$. It is typical that this share in the rural population was higher than in the urban population (Table 4).

Table 4. The share of extramarital births in the total number of births, \%

\begin{tabular}{c|c|c}
\hline Year & Whole population & Rural population \\
\hline 1945 & 24.4 & $\ldots$ \\
1955 & 16.9 & $\ldots$ \\
1965 & 13.0 & 14.5 \\
1975 & 10.7 & 13.7 \\
\hline
\end{tabular}

Source: [Ivanova, Mikheeva 1998: Table. 3].

According to the decree of 1944, in the birth certificate of children born outside a registered marriage, instead of information about the father it was obligatory to put a dash. During the period in which this "humane" rule was in effect (from 1945 to 1968), more than 15 million children received a dash in their passport [Tolts 2014: 161]. But society was not supposed to know anything 
about this. In the archives is a letter from the head of the Central Statistical Bureau (CSD) of the USSR to the Central Committee of the CPSU.

"To the CPSU Central Committee

14.01.1970

... In the article "Fatherlessness" of the 7.01.1970 issue of Literaturnaya Gazeta, Urlanis cites data on children of mothers not in a registered marriage which are not printed in the open press... Bourgeois propaganda can use [this] for hostile purposes, because in bourgeois countries such children are usually referred to as illegitimate ... The CSD asks that the attention of the editorial board of the Literaturnaya Gazeta be drawn to the inadmissibility of publishing data not subject to publication in the open press ...

Starovsky",2

\section{THE WAR AND FERTILITY}

It has been said above that the war launched a cycle of fluctuations in the size of cohorts one after the other, which, in particular, had a very strong effect on fertility. During the war, the number of births, and hence the number of those who were to become parents of new generations of children in about two decades, fell sharply, and this decline is repeated several more times with an interval of about 25 years.

The fall in the number of births in 1942-1945, especially great in 1943-1944, was not the first in the twentieth century, but it was much deeper than the previous ones. In 1943, when this fall reached the bottom, almost three times fewer children were born than in the years of the previous minima - 1917 and 1934. The postwar growth of fertility allowed the total number of births to return only for a short time to the level of these two minima (Figure 14).

The fluctuations in the number of births corresponded to the fluctuations in the number of women of maternal age that they generated. Figure 15 shows that, although these fluctuations gradually fade, they still remain very large. Approximately $80 \%$ of all children are usually born to women aged 20-34 years; a change in their number determines, though not in full, but to a decisive extent the dynamics of the country's maternal potential. Between 1984 and 1998 the number of women in this age group decreased by 3 million, stayed at this level for 3 years, and then between 1998 and 2010 again increased by 2.2 million, which largely led to the increase in the number of births in the "aughts". But then began a new cycle of reductions in the number of women of maternal age - the third after the war. Though it seems like the war was a very long time ago, in reality we are only somewhere in the middle of the third cycle - near the point of inflection, when the number of births again begins to decline.

\footnotetext{
${ }^{2}$ RSAE (Russian State Archive of Economics). Collection 1562, Inventory 47. Storage unit 35. Memorandum reports to the Central Committee of the CPSU and the Council of Ministers of the USSR on population and health statistics for 1970. Sheet 1 .
} 


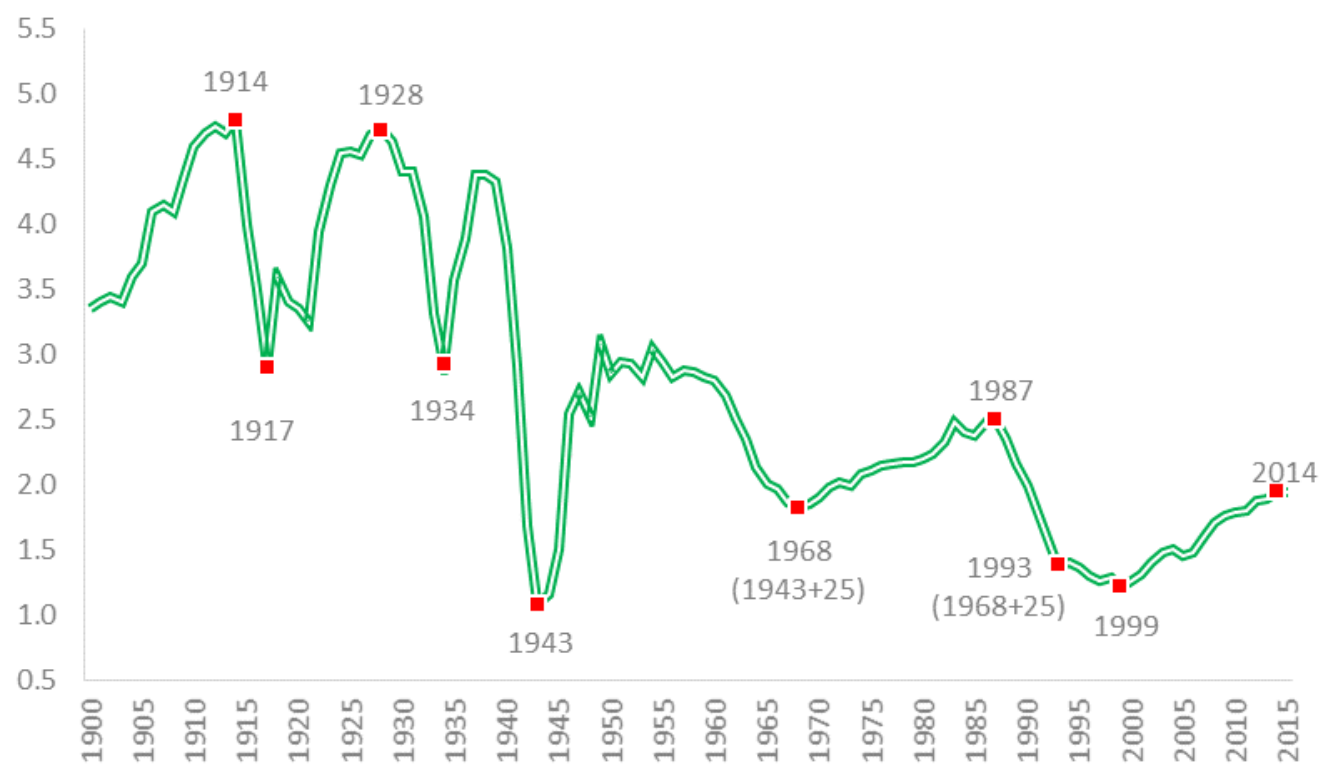

Figure 14. Number of births in Russia in 1900-2015, in millions

Sources: [Demographic modernization of Russia 2006: 184; Demographic Yearbook of Russia 2015: tab. 2.1].

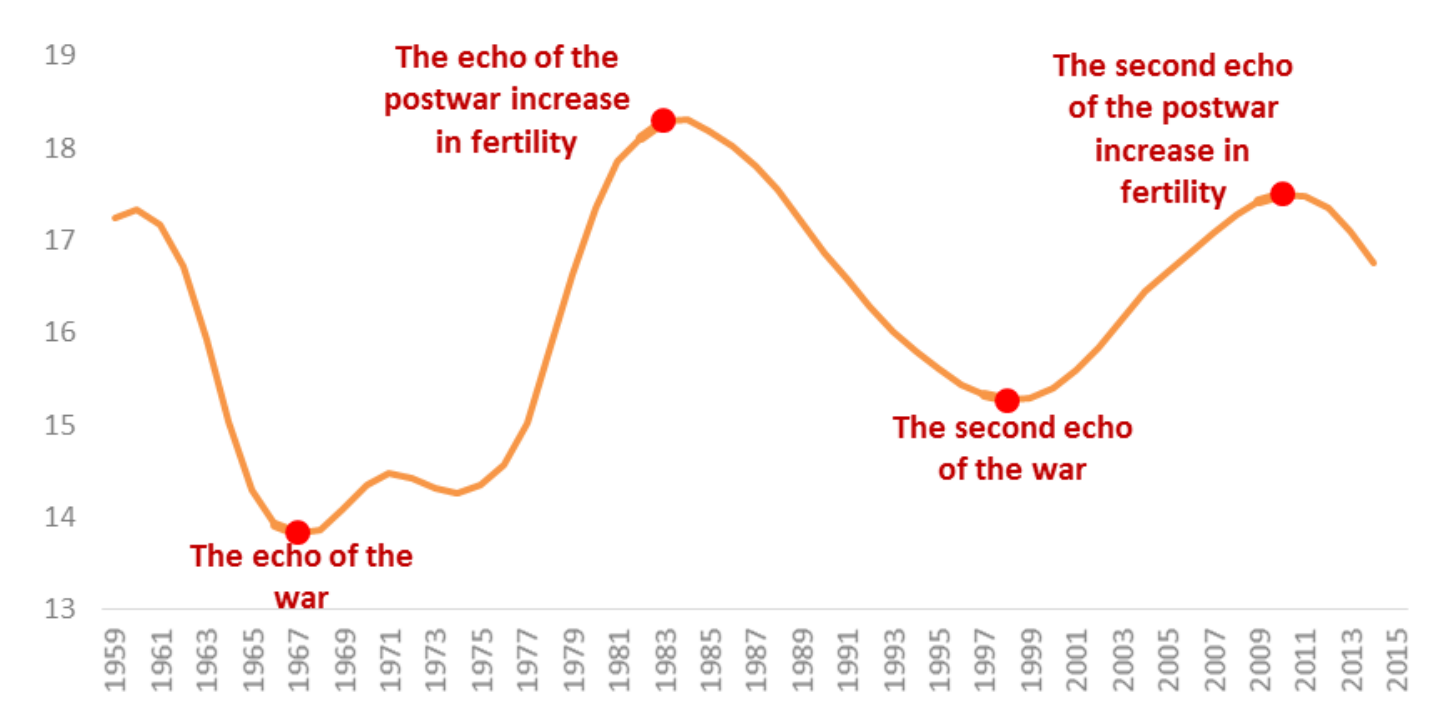

Figure 15. The number of women aged 20-34 years, in millions

Source: Demographic Yearbook of Russia for different years.

How much do these fluctuations affect the total number of births, which also depends on other causes?

Given the decisive contribution to fertility of mothers aged 20-34 years, in a first approximation and with a certain degree of conditionality, fertility can be measured by the number of births only in women 20-34 years old per 1,000 women of this age group. In demography, much more sophisticated indicators are used, but for rough estimations you can use this indicator, a kind of "general fertility rate" with narrower than usual limits of women's reproductive ages. Its changes over a long period of time indicate a decline in fertility in Russia. In 1984, when the number of women aged 20-34 reached their historical maximum (18.3 million), per 1000 women of this age group 132 children were born to women of all ages (15-49), while to women of precisely 
this age group 111 were born . This is significantly lower than, for example, in 1960, when these indicators were 162 and 130, respectively, although much higher than in subsequent years when they reached very low values (79 and 66 per 1000 in 1999). But for some time after 1984 these rates were still growing, counteracting the negative impact of the beginning of the decline in the maternal potential, and the number of births increased until 1987. However, then the decline in the number of women in the most productive maternal age joined with a decline in fertility, and the number of births in Russia began to decline. Later, after 1999, both factors began to act in the opposite direction, contributing to an increase in the number of births.

We can try to separate out the specific factors contributing to these changes - on the one hand changes in fertility due to current social and economic causes and policy measures, and on the other hand changes in the number of potential mothers on the descending and ascending branches of the waves of war-triggered fluctuations.

Figure 16 shows the actual (according to Rosstat) change in the number of births after 1984 under the influence of both factors, and its hypothetical change on the assumption that the fluctuations in the number of women aged 20-34 years after 1984 stopped, their number remained constant, and the changes in the number of births per 1,000 women in this age group corresponded to the actual changes. As we see, the change in the hypothetical number of births would still have the same direction as the actual one, but the fall in the absolute number of births would be less. With this assumption, in the three decades after 1984 (1985-2014) 55.5 million children would have been born in Russia, including 45 million to women aged 20-34. In reality, 50.7 million and 41.2 million were born, i.e. 4.8 and 3.8 million fewer, respectively. Taking into account the fact that for the whole thirty years the average number of births was 1.8 million per year, 4.8 million births that never occurred is quite a significant number.

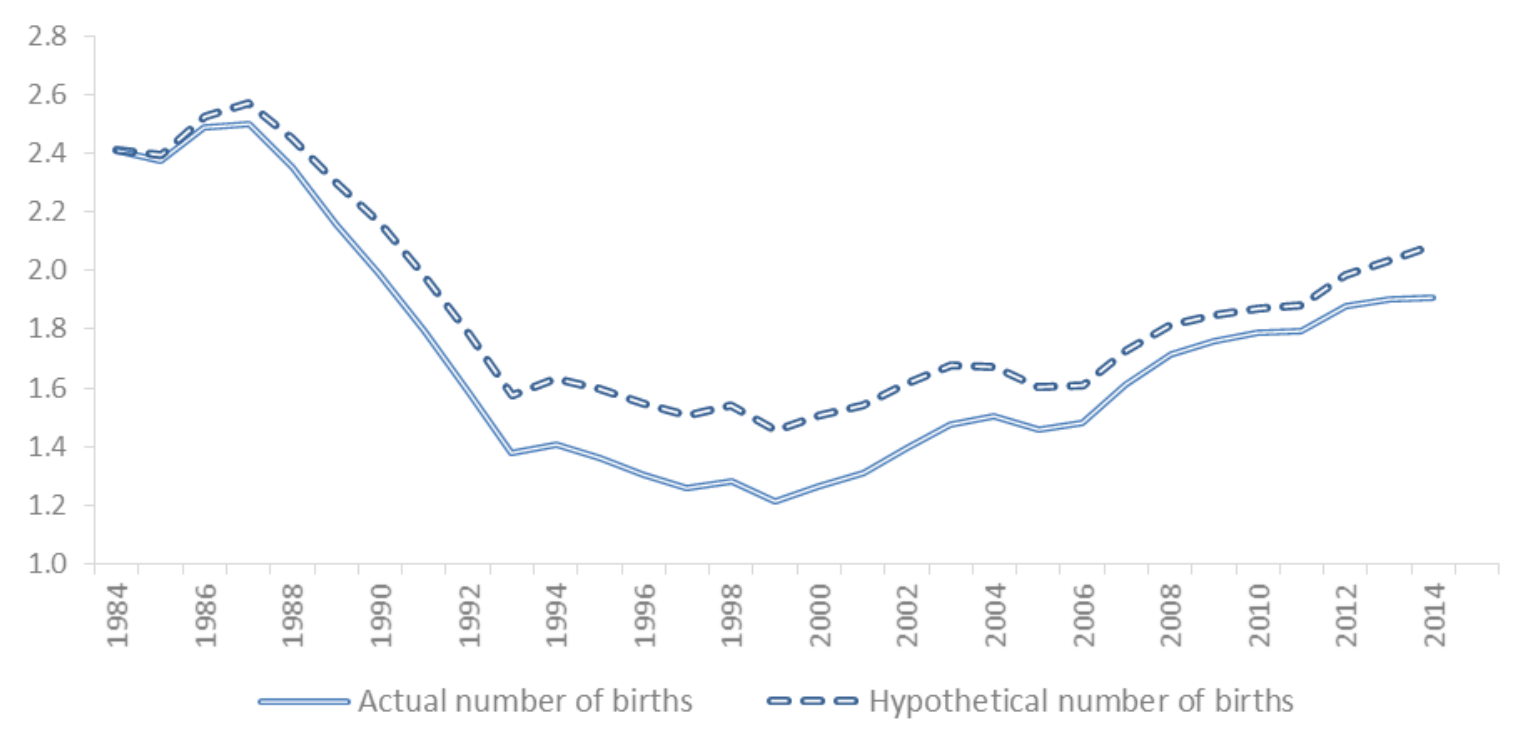

Figure 16. Actual and hypothetical (provided the number of women aged 20-34 remains constant at 1984 level) number of births, in millions

Figure 16 also draws attention to the fact that the gap between the two curves initially increases (until 1999), and then decreases. This is explained by the fact that the trajectory of the dotted curve (the hypothetical number of births) is determined by the action of only one factor- 
changes in the actual fertility, and the trajectory of the solid curve (the actual number of births) is also influenced by the change in the number of women. Until 1999, this last change contributed to a decrease in the number of births, and after that - opposed it.

\section{THE WAR AND NATURAL INCREASE OF THE POPULATION}

In 1992, the natural increase in the population of Russia became negative for the first time since the war. In the 1990s - 2000s, negative natural increase was observed in many countries of Europe, especially in Eastern Europe. But Germany was the first European country where the number of deaths exceeded the number of births (20 years earlier than in Russia). In Russia, then, the natural increase in population exceeded $6 \%$, and it seemed that the situation here was much better. However, this apparent well-being was poorly combined with the fact that fertility in Russia already in 1964 had fallen below the replacement level (the net reproduction rate had descended below 1), and ever since, with the exception of three "Gorbachevian" years (1986-1988), the net reproduction rate of the Russian population has been below this level. And in Germany, throughout the 1960s, the net reproduction rate exceeded 1 and fell below 1 only in 1970 (Figure 17).

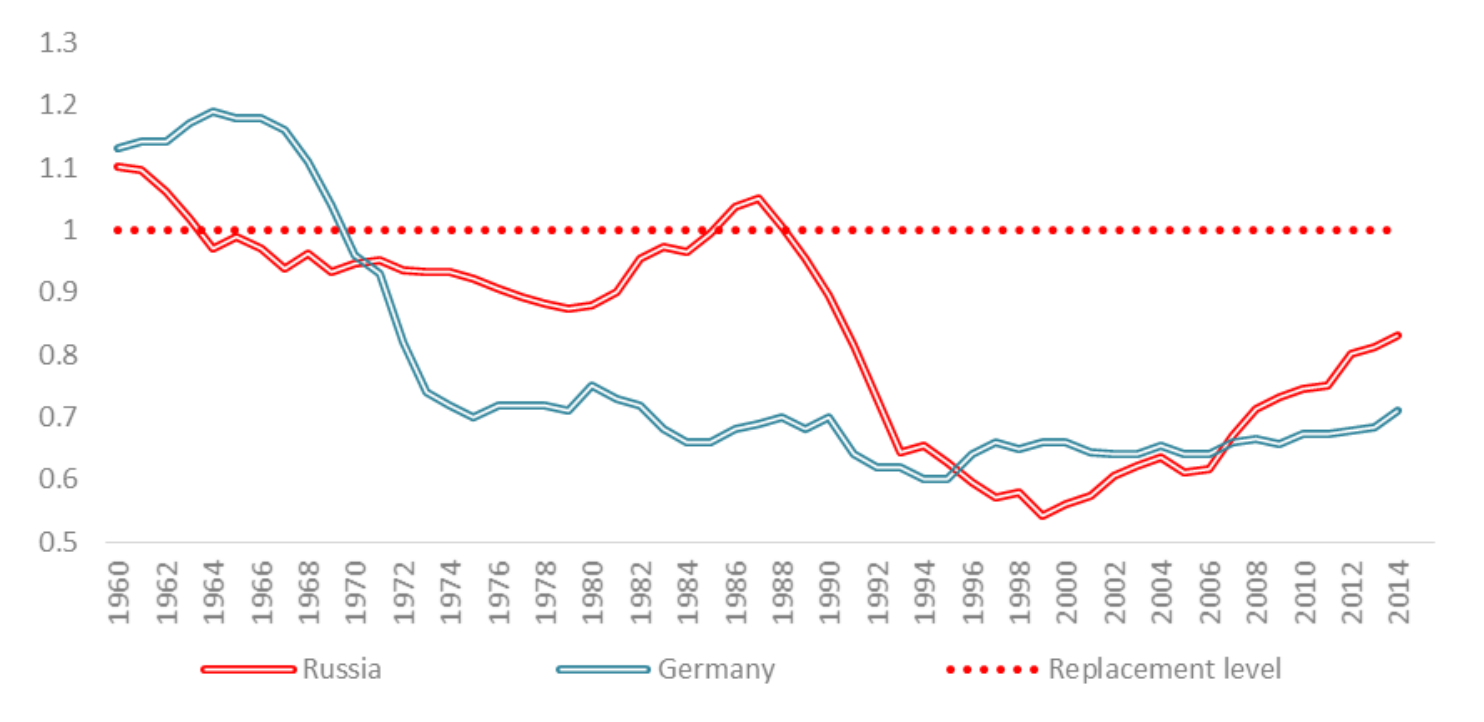

Figure 17. Net reproduction rate in Russia and Germany

Source: [Demoscope Weekly database]. URL: ttp://www.demoscope.ru/weekly/ssp/sng_rni.php (accessed June 22, 2016).

The long period of fertility below replacement level predetermined the intersections of the curves of total fertility and mortality rates (the so-called "Russian cross") and the appearance of a negative natural increase, but it appeared in Russia only in 1992, 20 years later than in Germany (Figure 18). 


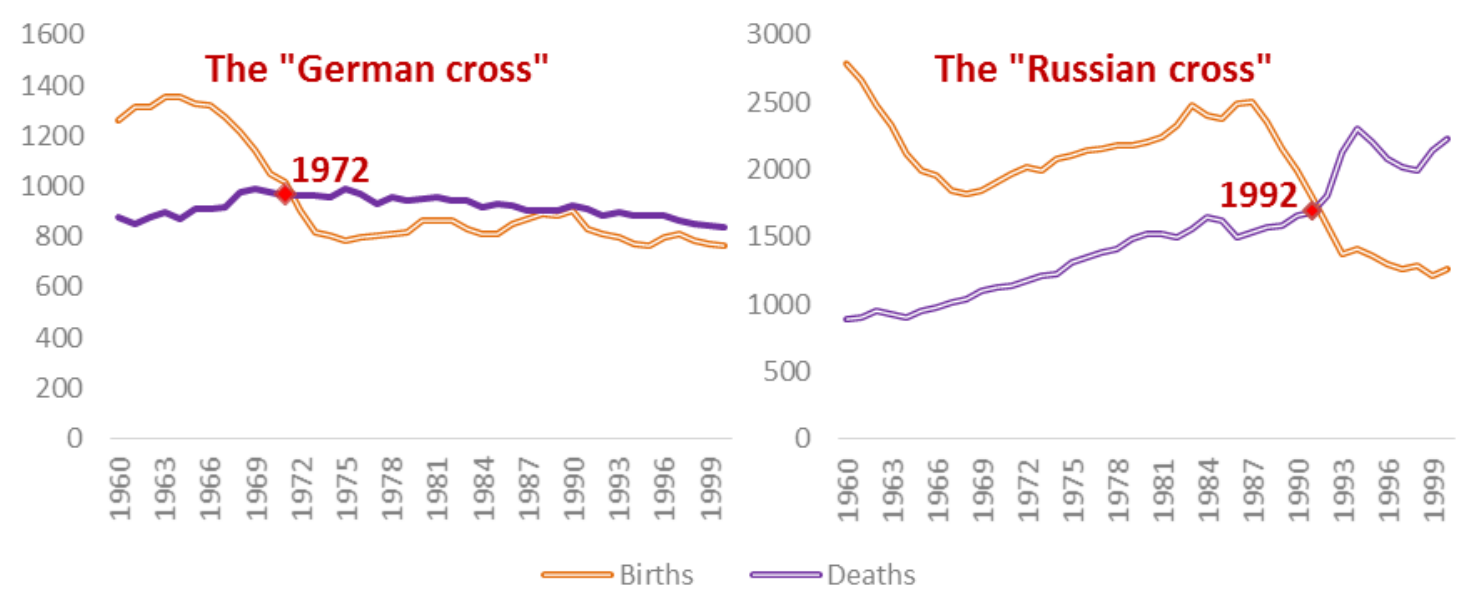

Figure 18. Natural increase in Russia and Germany, in thousands

Source: Demoscope Weekly database. URL: http://demoscope.ru/weekly/app/app4003.php (accessed: June 22, 2016).

The explanation of this paradox lies in the features of the post-war age and sex composition of the Russian population, including those that contribute to improving current indicators but did not at all indicate a real prosperity. Natural increase (decrease) is the difference between the numbers of births and deaths. In 1972, when a natural decrease appeared for the first time in Germany, there were 2,014,600 children born in Russia, and the total number of deaths came to 1,181,800, a natural increase of almost 833,000. With the same population as in Russia in 1972 (131.7 million people), and with the same age-specific fertility and mortality rates that were actually observed in Russia that year, but with the age-sex composition of the German population at that time, the picture in Russia would have been very different. The natural increase would have been not 832,800 people, but only 18,500, and in the next year, 1973, like in Germany, it would have become negative (table 5, figure 19).

Table 5. Natural increase in Russia in 1972, actual and with age-sex composition of the German population, thousands

\begin{tabular}{lr|c}
\hline & Actual & With sex-age composition of the population of Germany \\
\hline Number of births & 2014.6 & 1768.2 \\
Number of deaths & & \\
Men & 579.2 & 954.4 \\
Women & 602.6 & 795.3 \\
Total & 1181.8 & 1749.7 \\
Natural increase & 832.8 & 18,5 \\
\hline
\end{tabular}

It would seem we should be happy that the actual number of deaths in 1972 turned out to be much less than the hypothetical one corresponding to the gender and age structure of Germany. However, one must take into account that the number of deaths depends on the number of people at risk of death at different ages. With the Russian population size of 1972, but with the sex and age composition of Germany, in Russia there would have been 11.4 million people aged 50 and over (including 6.7 million men) more than in reality, and correspondingly there would have been more deaths. But in 1972, these people were no longer alive.

1972 was not, of course, an exception. The vast majority of those who, by age, should have died in the 1970s - 1980s, had died earlier, most on the field of battle. If we apply the sex and age 
proportions of the population of Germany to the actual population of Russia and calculate the hypothetical natural increase in the population of Russia while maintaining the actual Russian agespecific rates of fertility and mortality of every year, one can see that the natural decrease would appear only a year later in Russia than in Germany, in 1973, and most certainly not in 1992 (Figure 19).

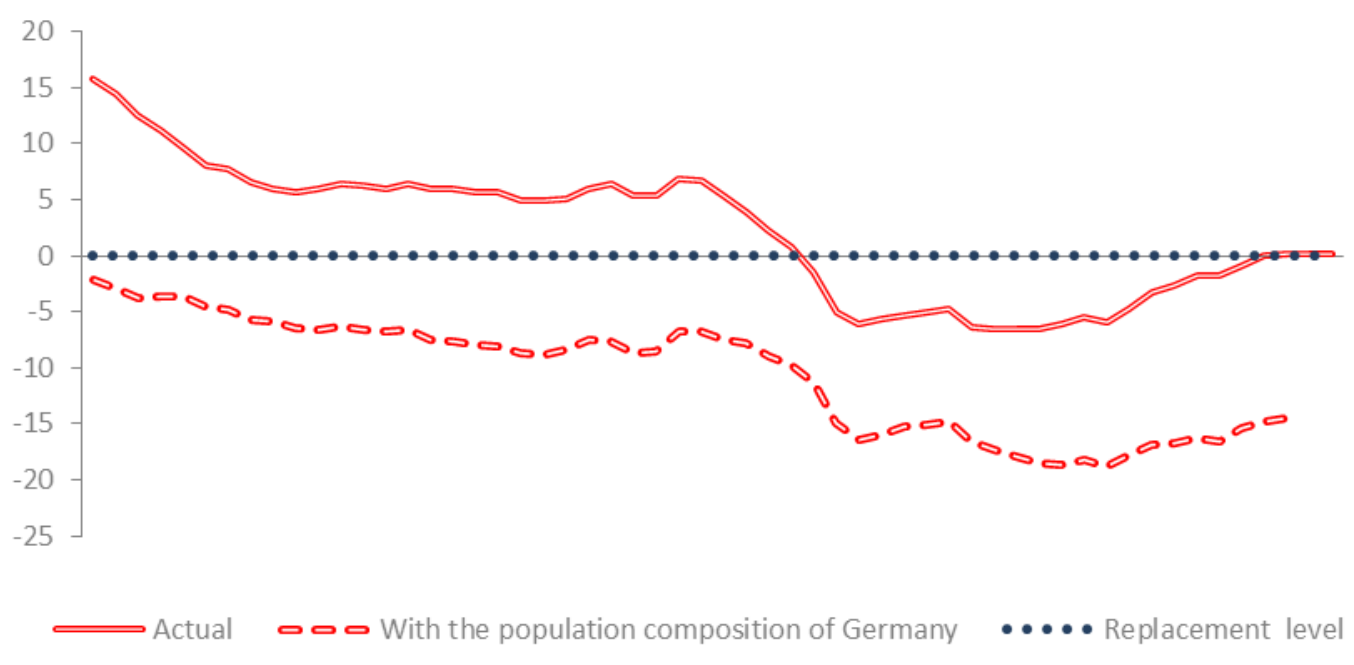

Figure 19. The natural increase in Russia, actual and hypothetical with the age and sex composition of the population of Germany, \%o

\section{THE WORKING AGE POPULATION AND THE DEPENDENCY RATIO}

The cyclical fluctuations in the size of generations caused by the war have a huge economic, and perhaps political, significance, which is not always recognized.

In particular, they lead to extremely uneven dynamics of the number of labor resources formed by generations entering and leaving the working age. Figure 20 shows the annual ratios of the numbers of young people entering working age and of older people exiting it, beginning in 1959 (20 and 60 years are taken as the lower and upper boundaries of the working age). During this time, Russia experienced at least three periods of deterioration in the "entry-exit" ratio for working ages, when small generations of workers born in periods of low fertility (war and its two echoes around 1968 and 1993) took over for the numerous generations born 40 years earlier. One more period of worsening of this ratio, though less significant, coincides not with a decrease in the number of those entering working age, but with an increase in those leaving it, those who were born in the period of a short-term rise in fertility in the late 1930s. 


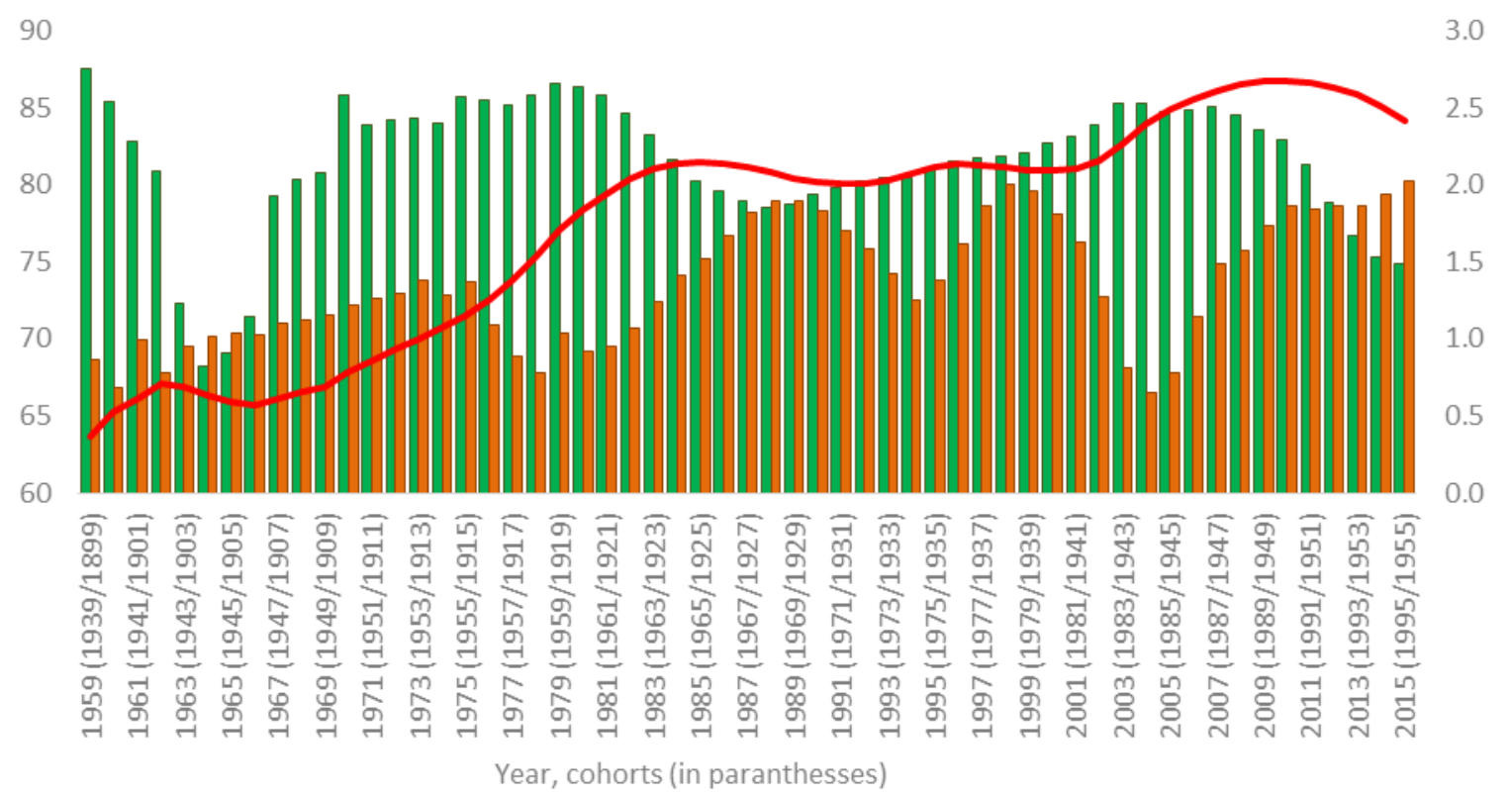

Entry of the generation into the working age ( 20 years: the year of birth - the first date in parentheses)
The exit of the generation from the working age ( 60 years: the year of birth - the second date in parentheses)
The population at working age ( $20-59$ years)

Figure 20. Population at working age in 1959-2014 (left axis), entry into this age (20 years) and exit from it (at 60 years) by generation (right axis), million people

Source: Demographic Yearbook of Russia for different years.

The cyclically changing proportion of incoming and outgoing generations results in a wave-like dynamics of the working-age population size (Figure 21). Such dynamics hamper the sustainable growth of the economy, which is forced to constantly adapt to the changing situation in the labor market.

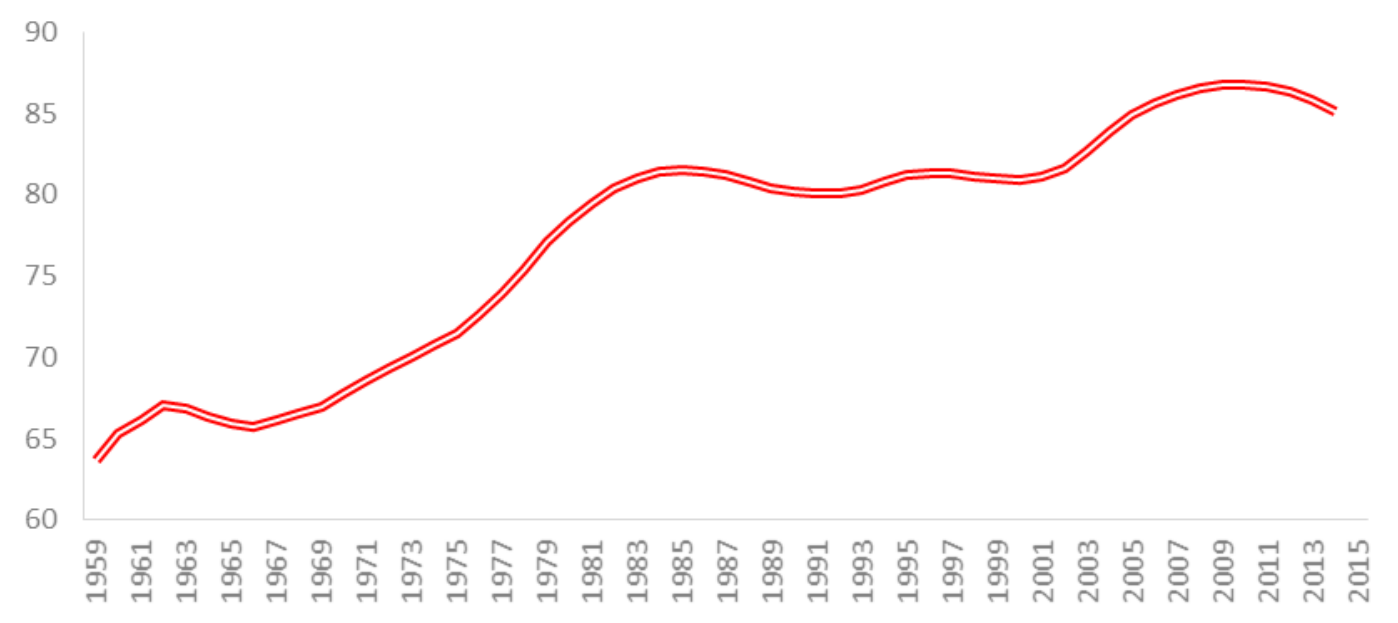

Figure 21. Population at working age (20-59 years), millions

Source: Demographic Yearbook of Russia for different years. 
But probably of even greater economic and social importance are the differences in the magnitude of the dependency ratio, and hence the burden of social expenditures on health, education, and social security of the unemployed population, i.e. mainly the population of preworking and post-working ages.

If we begin with the 1959 population census, the overall trend of changes in the aggregate dependency ratio was its decrease due to a reduction of the child dependency ratio, which for a long time successfully counteracted the growth of the old-age dependency ratio. At the same time, both parts of the dependency ratio, once very different, converged. If in 1959 the old-age dependency ratio (60 years and older) was 17 per 100 people aged $20-59$ years, and the child dependency ratio (up to 20 years) was 67 per 100, by 2014 they were almost equal: 33 and 36 per 100, respectively (Figure 22). But we already know that all such changes throughout the postwar period had an oscillatory character, and this led to significant differences in the dependency ratio in a relatively short time. Thus, the combined child and the old-age dependency ratio was very high in the second half of the 1960s (94 people of pre-working and post-working ages per 100 people of working age), but by 1982-1983 had decreased by more than $20 \%$, to 74 per 100 . Then, in less than 10 years, it again increased by $15 \%$, to 84 per 100 in 1992. After that, the dependency ratio declined slowly during the 1990s and quickly in the 2000s, reaching an all-time low in 20082011 of 65 to 100, or almost a quarter less than in 1992 and more than $30 \%$ less than in the late 1960s. Then a new growth began, which will inevitably continue.

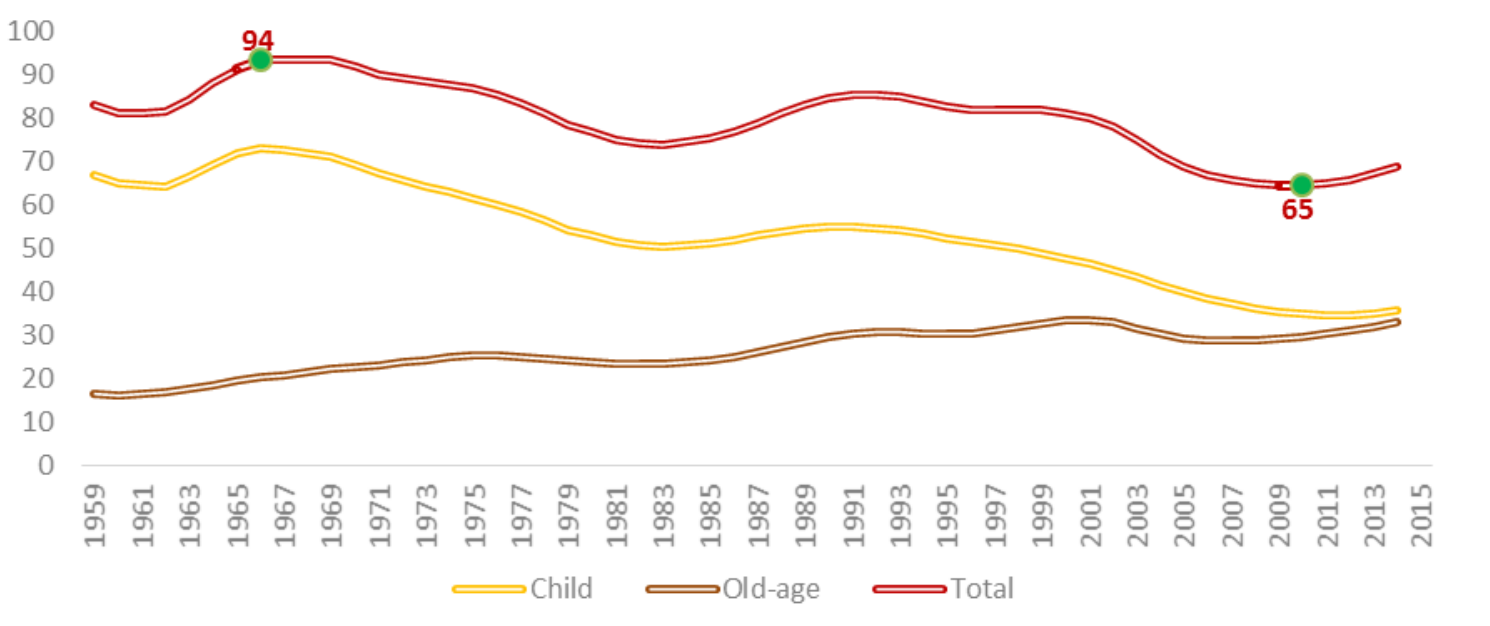

Figure 22. Dependency ratio per 100 people at working age (20-59 years)

Source: Demographic Yearbook of Russia for different years.

Public opinion and even many experts, not to mention politicians, usually do not attach much importance to such changes if these changes do not manifest themselves in a very obvious and, as a rule, negative way. In the favorable (and sometimes even unfavorable) demographic changes due to war-induced fluctuations in the size of generations, the authorities always tend to see their own merit, the fruits of their own policies, forgetting that in both cases these are but the repercussions of a terrible misfortune.

In the 2000s, few people realized both that there was an exceptionally favorable situation with the demographic burden in the country, and that this situation was a gift from a distant and hardly joyful past, and could not last long. 
Demographic aging as a consequence of the demographic transition is taking place in all countries, including Russia, but in Russia it has several times come to a brief halt, when the generations born in the hard times of the first half of the twentieth century reached older ages (Figure 23). At that time, the old-age dependency ratio, and hence the burden on the pension system, did not increase, but decreased, while the easily predictable resumption of growth in the burden always seemed unexpected.

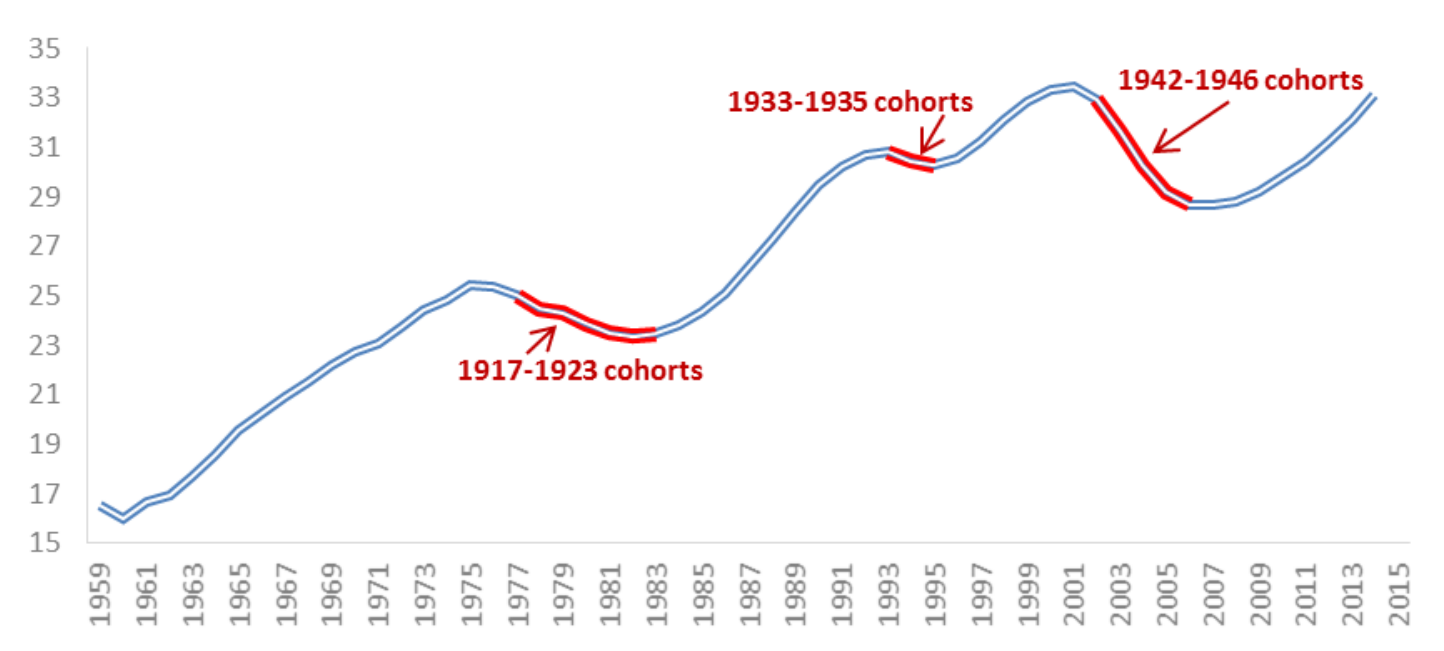

Figure 23. The old-age dependency ratio per 100 persons aged 20-59 years and the years in which different generations reached age 60

Source: Demographic Yearbook of Russia for different years.

The biggest decrease occurred very recently, in the past decade. A significant part of the economic well-being of the "fat" 1990s was due to an unprecedented low dependency ratio resulting from a halt in the population's aging. This temporary halt was owed to the fact that at this time the small generations of those born in the catastrophic war years were now reaching retirement age. The economy and politics reaped all manner of benefits from this.

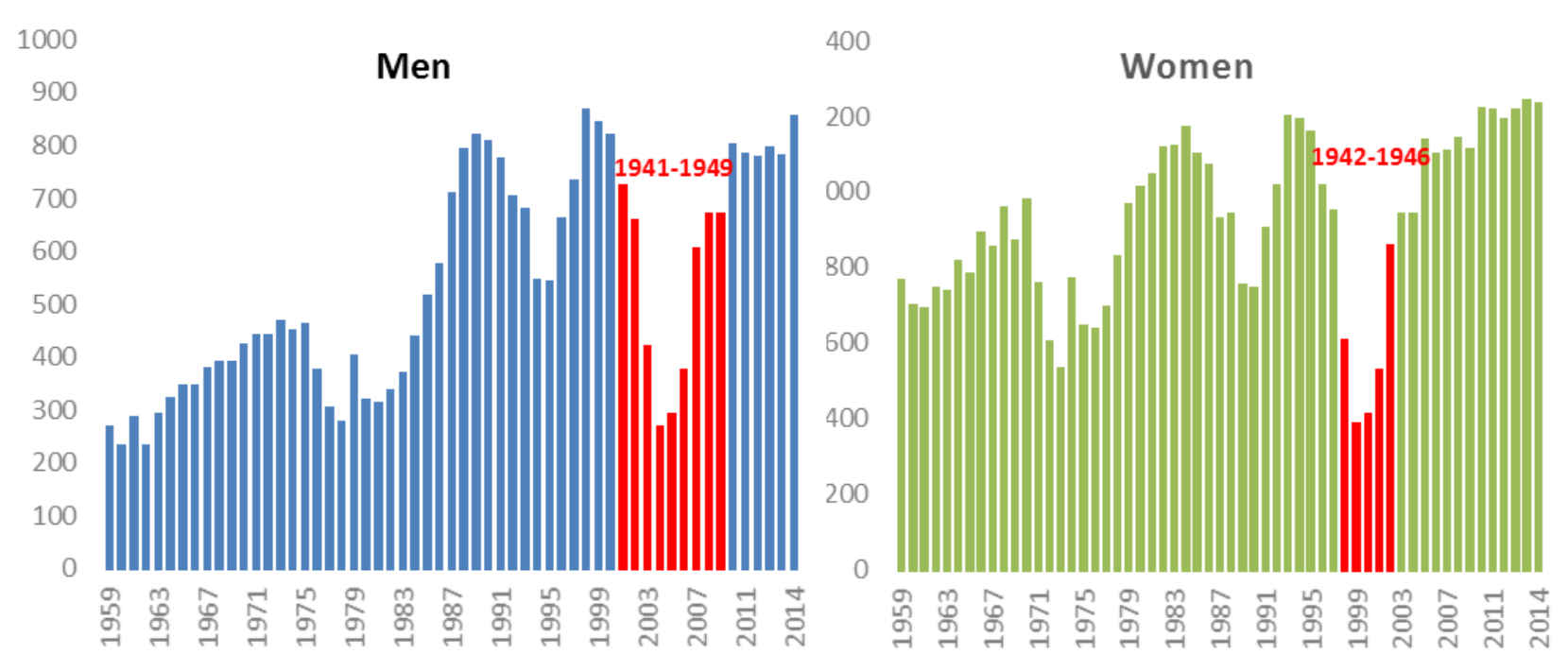

Figure 24. The number of men and women reaching retirement age (55 years for women and 60 years for men) in 1959-2014, thousands

Source: Demographic Yearbook of Russia for different years. 
But the small wartime generations were followed by the numerous post-war ones, and this entailed a new growth in the old-age dependency ratio and in the burden on the pension fund (Figures 24 and 25).

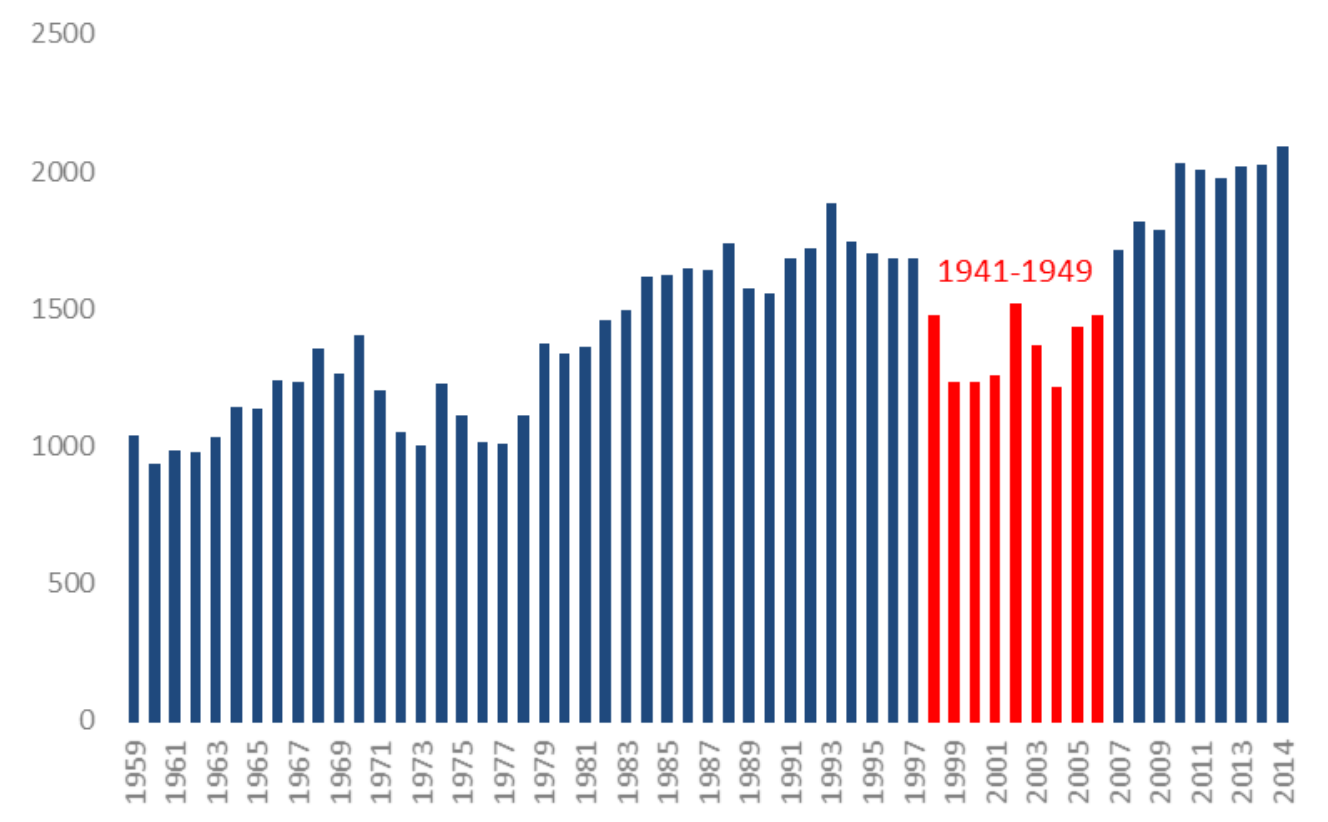

Figure 25. The population of both sexes reaching retirement age ( 55 years for women and 60 years for men) in 1959-2014, thousands

Source: Demographic Yearbook of Russia for different years.

This growth seems especially large, because it comes after a "hole" formed by wartime generations. Though quite predictable, it was unexpected for many, who began to come up with various explanations like the one given in an "analytical report" prepared on the instruction of the Minister of Health, which states that the 2006 increase in the proportion of older people in the country from $20.5 \%$ to $23.5 \%$ was due to "demographic changes that led to an increase in life expectancy"3.

\section{COULD THERE HAVE BEEN FEWER MILITARY LOSSES?}

War is war: the warring parties inevitably suffer human losses. But such losses as the USSR suffered in 1941-1945 had never been seen in history. Estimates for these losses vary widely. L. Rybakovsky gives a summary of 28 different estimates, which range from 7 million people announced by Stalin in 1946, to 46 million calculated by one researcher [Rybakovsky 2010: 26]. But still the bulk of estimates are concentrated in the range of 26-27 million people, of which about half (13 million according to Rybakovsky's estimates [Rybakovsky 2010: 103]) falls on Russia. Based on these figures, the USSR accounted for one-third to one-half of the total losses of the countries participating in the Second World War [Vishnevsky 1998: 387], with Russia's share being between $16-17 \%$ and $25 \%$. It is not surprising that the demographic echo of these losses is

\footnotetext{
${ }^{3}$ Living longer to work more. The Ministry of Health and the Federal State Statistics Service are exploring the reasons
} for increasing the retirement age. "Kommersant" №145 of August 13, 2015. 
still heard in Russia today.

How to explain such high losses? Victory in the war was indispensable, but did it really require such a high price? Were these losses caused by the USSR's lesser military might? By the unexpectedness of war? By the mistakes of the country's political leadership, who incorrectly assessed the international situation on the eve of the war, or failed to draw conclusions from its assessment?

To try to answer these questions, we will have to return to 1939, where we began our article. The already mentioned $18^{\text {th }}$ Congress of the CPSU (b), the main event of political life in the USSR at the time, is important for our topic not only because it was here that Stalin stated the size of the population. Much more important is that it assessed the international situation in relation to the approaching war.

In particular, Stalin's report spoke of the already begun new imperialist war, the characteristic feature of which was that "it has not yet become universal, a world war. The war is being waged by aggressor states, who in every way infringe upon the interests of the nonaggressive states, primarily England, France and the U.S.A., while the latter draw back and retreat, making concession after concession to the aggressors" [Stalin 1978]. By aggressor states he meant Germany, Italy and Japan, at the same time stressing that "non-aggressive, democratic states" "have tremendous opportunities" and "taken together, are unquestionably stronger than the fascist states both economically and militarily" [Stalin 1978].

The theme of superiority over the fascist states was developed in the report after Stalin's, of the ACP(b) delegation in the Executive Committee of the Comintern, presented by D.Z. Manuilsky. "In order to defeat the fascist aggressors, actions are needed, backed by arguments of material force, actions by states against which, in essence, the fascist aggression is directed (France, England, USA)... Fascist Germany is not ready for a large, serious war: it does not have enough raw materials or food, its financial situation is critical, its shores are vulnerable to a naval blockade, its army lacks command staff, its rear is a dangerous rear for fascism. The advantages of material power are undoubtedly on the side of the so-called Democratic states. These states have a population three times greater than the aggressor bloc, produce $1 \frac{1}{2}$ to 2 times more steel, generate twice as much electricity, produce fourteen times more cars, produce fifty-five times more liquid fuel, nine times more textile raw materials, four times as much food; they can fully cover their raw material needs, while the block of aggressors even in peacetime has a deficit of 50-55\%; their gold reserves are forty-nine times greater than the reserves of the fascist states. Their production capabilities in aircraft construction, motorization of the army and its military-technical equipment far exceed the boldest calculations of the fascist bloc; the navy of France, Britain and the USA is twice as strong as the fleet of Germany, Italy and Japan "[ S'yezd VKP(b) 1939: 57]

The delegates of the congress were very cheerful. Stalin sneered at the "fascist rulers" and the hall appreciated his humor, as the remarks in the transcript of the congress show, although they were omitted when the report was published in the collection of Stalin's works. "The fascist rulers decided, before plunging into war, to frame public opinion to suit their ends, that is, to mislead it, to deceive it. A military bloc of Germany and Italy against the interests of England and France in Europe? For goodness' sake, you call that a bloc? "We" have no military bloc. All "we" have is an innocuous "Berlin-Rome axis"; that is, just a geometrical equation for an axis. (Laughter.) A 
military bloc of Germany, Italy and Japan against the interests of the United States, Great Britain and France in the Far East? Nothing of the kind. "We" have no military bloc. All "we" have is an innocuous "Berlin-Rome-Tokyo triangle"; that is, a slight penchant for geometry. (General laughter.)" [Stalin 1978]. "It is quite possible, of course, that there are madmen in Germany who dream of annexing the elephant, that is, the Soviet Ukraine, to the gnat, that is, to the so-called Carpathian Ukraine. If there really are such lunatics in Germany, rest assured that we shall find enough straitjackets for them in our country. (Thunderous applause.)" [Stalin 1978].

It should be recognized that if we reject the propaganda rhetoric, then the analysis of the balance of forces on the world scene presented at the Congress was correct. In general, this was confirmed by the course of the war, albeit with considerable reservations.

When the war ended, the idea was again expressed of the initial superiority of the victors, of the "enormous advantages of a coalition of democratic states that had far superior capabilities and reserves in economics and technology to win a world war. These advantages can also be seen from a comparison of the populations. The democratic states - the USSR, the USA and England had a population of 372 million people, while the fascist states - Germany, Japan and Italy - had 186 million people." [Voznesenskii, 1948]. Once again this is not just a personal point of view, even if of a very high-ranking author. After publication, the book was awarded the Stalin Prize of the first degree, and there is evidence that "Stalin read the manuscript with pencil in hand, and made notes and even some insertions" [Congress of the CPSU 1962: 184].

But how to reconcile such superiority with such losses?

Any comparison is lame, but still some parallels arise. On December 7, 1941, several hundred Japanese aircraft ("without declaration of war") attacked the US military base of Pearl Harbor, after which the United States, the United Kingdom and a number of their allies declared war on Japan.

Japan was not at all an easy opponent. Its population in 1941 (73 million people) was about the same as the population of Germany (72 million), whereas the US population at that time (132 million people according to the 1940 census) represented about two-thirds of the USSR's (197 million In June 1941). In addition, Japan owned colonies (including Korea) with a population of over 30 million people, and controlled significant areas of China, including the puppet state of Manchukuo with a population of over 40 million people. Japan had long been preparing for and waging war, it occupied significant territories in Asia and Oceania, the development of its industry was subordinated to military tasks, the country's politics were under control of the military, and the majority of the population fanatically supported the aggressive imperial goals of the country's leadership.

The war that began after Pearl Harbor was in the huge Pacific theater. Its first stage was unsuccessful for the US and its allies, but then a turning point came with the naval Battle of Midway in June 1942. The war lasted for over three more years, but with the clear superiority of the United States. The difference in the military and economic potentials of Japan and the United States was enormous, and this predetermined the outcome of the war: the Japanese were driven out of all the territories they occupied, and military operations moved to Japanese soil. The US war against Japan neutralized and then eliminated an extremely dangerous threat for the USSR 
from one of the corners of the "triangle", the ironic mention of which in Stalin's report was met with the "general laughter" of the delegates of the XVIII Congress of the ACP(b).

In the course of this far from simple war with Japan, lasting, like the Great Patriotic War, from 1941 to 1945, total US losses of servicemen killed, dead in captivity or missing in action came to about 120,000 [1946: 8; CRS (2001): 3]. This is less than the irretrievable losses of Soviet troops in the Soviet-Finnish war of 1939-1940 (127,000 dead), and only 10 times more than were lost in about 25 days of military operations against the Kwantung Army in Manchuria after the USSR joined the war against Japan on August 9, 1945 (over 12,000 people) [Grif sekretnosti 1993: 121, 223]. By this time, Japan's military power was already weakened, and Japan had twice been subjected to atomic bombing. On August 15, Emperor Hirohito, addressing the nation on the radio, announced the surrender of Japan, but the Kwantung Army continued to resist until September 2, without, of course, any chance of success.

And how did the balance of world forces noted during the $18^{\text {th }}$ Congress of the ACP(b) work in the case of the USSR?

For several months after the congress, the Soviet Union negotiated with England and France and simultaneously with Germany. There is a vast literature in which all the issues of the European diplomatic game of the summer of 1939 are discussed in detail, and the steps of the Soviet leadership of the time are condemned or justified. But for us what matters now is the result: Soviet diplomacy did not reach an understanding with "non-aggressive democratic states", but rather quickly found a common language with adventurist "fascist rulers", which led to the signing on August 23 of the Soviet-German Non-Aggression Pact (the "Molotov-Ribbentrop Pact"), and then (September 28) of the Frontier Treaty.

As General Sudoplatov, one of the heads of Soviet intelligence, responsible before the war precisely for the German sector, stated in his memoirs, "Stalin's policy toward Hitler was based on the correct belief that the hostility of the Western world and Japan to the Soviet system would make the USSR's isolation from the international community a constant factor "[Sudoplatov 1997: 146-147]. The meaning of this phrase is difficult to understand, especially against the background of what Stalin himself said several months before at the Congress about "politics towards Hitler". Much more understandable are the reflections of the intelligence officer on how "the secret consultations of Hitler, Ribbentrop and Molotov on a possible strategic agreement between Germany, Japan and the Soviet Union created the illusory idea in Stalin and Molotov that it was possible to reach agreement with Hitler," and his perplexity about the fact that "the military leadership and Stalin's entourage harbored the illusion that the might of the Red Army was equal to the strength of the Wehrmacht forces concentrated near our western borders. Why such a miscalculation?" "No one in the state security service seriously studied the real balance of forces on the Soviet-German border" [Sudoplatov 1997: 175, 180-181].

But it seems that Sudoplatov himself did not think, given the degree of trust that was established between the two countries' leaders, that such a study was necessary. Explaining why intelligence refused to use a valuable agent who had access to the top officials of the Reich, he writes: "Before Germany unleashed a war against us, there were in fact no problems where he could have been used to probe the position of the Germans on this or that delicate matter: after all, all this time Molotov and our Ambassador Dekanozov maintained a confidential relationship with 
Ribbentrop and the German Ambassador, Schullenburg" [Sudoplatov 1997: 172]. So what exactly then was the intelligence service of "the German sector" doing? "As soon as Stalin learned that the German General Staff was conducting exercises on operational-strategic and materialtechnical supplies in the event of a protracted war, he immediately gave the order to acquaint the German military attaché in Moscow with the industrial and military might of Siberia. In April 1941 (!) he was allowed to travel to new military plants that produced tanks of the newest designs and aircraft. Through our residency in Berlin, we spread rumors in the ministries of aviation and the economy that the war with the Soviet Union would turn into a tragedy for the Hitlerian leadership "[Sudoplatov 1997: 176]. Thus did we prepare for war.

L. Rybakovsky, perhaps the person most involved in the study of the military losses of the USSR and Russia, introduced a strange formulation: "Stalin, by agreeing to a nonaggression pact with fascist Germany, did not make a mistake, but he did make a huge strategic miscalculation" [Rybakovsky 2000: 94; 2010: 19]. But his general conclusion still says that "the huge size of human losses is largely due to the criminal activities of Stalin and his entourage [in the book version - of his "clique"]; to strategic miscalculations committed on the eve of the war; to stubborn reluctance to reckon with the realities of the war, especially in its first stage" [Rybakovsky 2000: 94; 2010: 18].

Apparently, Stalin and his entourage were quite clearly aware that such losses were not justified, and did everything to hide their true scope. This manifested itself not only in the fact that Stalin informed the whole world of the absolutely unrealistic magnitude of the losses -7 million people - while knowing that it was greater, but also that he banned any attempts to count the postwar population of the USSR. Well aware of Stalin's reluctance to name the true magnitude of the losses, the then head of the Central Statistical Bureau of the USSR, V. Starovsky, still believing that "for practical needs it is necessary to have data on the current population size ... and ... composition," suggested that a one-time population count should be made, stipulating that this would not be a census, and that "unlike the results of a census, the results will not be subject to publication, as is customary in international practice", but he was instructed by Stalin "to postpone [it] until the end of the five-year plan" [Demographic modernization of Russia 2006: 459]. After this instruction, received August 29, 1947, Stalin lived over 5 more years, but the question of counting, and all the more of conducting a census, no longer arose. And even after Stalin's death, the size of the Soviet Union's military losses for a long time was surrounded by a veil of secrecy, and the very same V. Starovsky did what he could to oppose its declassification. A secret note "of special importance" to the Central Committee of the CPSU dated November 14, 1956 has survived. Here is its full text ${ }^{4}$.

"Of special importance

Comrade Shepilov asks to telegraph the figures to be published on the losses of the Soviet army and the Soviet people during the Second World War.

${ }^{4}$ RSAE, Collection 1562, Inventory 33, File 2990, Sheet 75. 
In connection with this, I report:

a) In an interview with I.V. Stalin, published in the press on March 14, 1946, it was said: "... As a result of the German invasion, the Soviet Union irretrievably lost in battle with the Germans, and also as a result of the German occupation and the forcing of Soviet people into German hard labor, about seven million people. In other words, the Soviet Union lost several times more people than Britain and the United States of America combined."

b) According to the calculations of the Central Statistical Bureau, the decrease in the population of the USSR during the war years as a result of the Soviet army's losses, the extermination of Soviet people by occupants and the excess of deaths over births was over 20 million people;

c) From figures published in a statistical bulletin of the CSO [Central Statistical Office] on the population of the USSR for 1940 (191.7 million) and for April 1956 (200.2 million), as well as from data on population growth published in recent years, it can be concluded that the losses of the USSR in the war came not to 7 million, but significantly more.

I therefore would consider it necessary to instruct comrade Shepilov either not to name the number of losses, by limiting himself to the phrase "many millions", or to name the figure over 20 million people - by wording it roughly as follows:

"During the Great Patriotic War the Soviet Union lost in battles with the invaders, as a result of the slaughter of the population by the invaders, as well as from the decrease in fertility and the increase in mortality, especially in the occupied areas, over 20 million people."

\section{I await instructions."}

At that time, Shepilov was considerably higher-ranking than Starovsky, but he apparently received an appropriate "instruction", because the new figure of losses ("more than two tens of millions of lives of Soviet citizens") was announced by Khrushchev only 5 years later [Khrushchev 1961: 8], and then corrected already in strict accordance with the recommendation of Starovsky ("more than 20 million people") [Brezhnev 1965: 15]. As D. Bogoyavlensky rightly points out, "We can assume that the basis of the figures for both Khrushchev and Brezhnev was first pointed out by Starovsky in this note. By the way, "Gorbachev's" "almost 27 million" formally corresponded to the "over 20 million people" in the letter from the head of the Central Statistical Office of the USSR. Apparently, the CSO had nonetheless made its own calculations of the losses, for which Starovsky deserves a large part of the credit. But it is also true that he considered it perfectly normal to conceal from the people and from the whole world the true extent of the losses, and was looking for ways to continue to withhold the figures at his disposal in the changed political situation. Even in his top-secret letter, Starovsky does not give specific figures, but only evasive and "rounded" estimates. In addition, he was mistaken, and maybe even dissembling, when including in his proposed formulation losses from a decline in fertility. Such losses, albeit hypothetical, did of course occur, but with them the "price of Victory" would have been even greater" [Bogoyavlensky 2012].

It did indeed turn out to be greater. All the post-war population censuses testify to this, as well as to how hard and how long the demographic wounds caused by the war took - and continue 
to take - to heal. And the question remains: why were they so deep? The famous words from the Okudzhava song - "We need one victory, one for all - whatever it may cost" - do not give all answers to this question. The Soviet Union fought a strong, but not a stronger enemy, and it fought on the side with much greater economic and military might, which, as we have seen, was clear to the political leadership both before and after the war.

The very fact that instead of looking for an answer to the question of the causes of such unprecedented losses, the leaders of the country did all they could to avoid the question itself, says a lot. In understating and concealing the real extent of the losses, they hoped that time would wash away the truth, leaving only the memory of victory.

But "there is nothing hidden that will not be disclosed, and nothing concealed that will not be known or brought out into the open" (Luke, 8:17).

\section{REFERENCES}

Andreev E.M., L.Yu. Darskiy, T.L. Kharkova (1993). Naseleniye Sovetskogo Soyuza: 19221991 [The population of the Soviet Union: 1922-1991]. Moscow: Nauka.

Andreev E.M., L.Yu. Darskiy, T.L. Kharkova (1998). Demograficheskaya istoriya Rossii: 19271959. [The demographic history of Russia: 1927-1959]. Moscow: Informatika.

Army (1946). Army battle casualties and nonbattle deaths in World War II. Final Report. 7 December 1941 - 31 December 1946. Statistic and accounting branch of Adjutant General.

Bashkin A., Ye. Nazarov (2014). Byla li perepis' 1939 goda sfal'sifitsirovana? [Was the census of 1939 falsified?]. URL: http://statehistory.ru/4567/Byla-li-perepis-1939-g-sfalsifitsirovana-/ (accessed: 22.06.2016).

Baza dannykh Demoskopa Weekly [Database of Demoscope Weekly]. URL: http://demoscope.ru/weekly/app/app40nrr.php (accessed: 22.06.2016).

Bogoyavlensky D. (2012). Kak utaivali velichinu voyennykh poter' [How the military losses were concealed]. Demoscope Weekly. №513-514. URL: http://demoscope.ru/weekly/2012/0513/arxiv01.php (accessed: 22.06.2016).

Brezhnev L.I. (1965). Velikaya pobeda sovetskogo naroda [The great victory of the Soviet people]. Moscow: Politizdat.

CRS (2001). CRS Report for Congress. U.S. Prisoners of war and civilian American citizens captured and interned by Japan in World War II: The Issue of compensation by Japan. Updated July 27, 2001.

Demograficheskaya modernizatsiya Rossii, 1900-2000 [Demographic modernization of Russia, 1900-2000] (2006). A.G. Vishnevsky, ed. Moscow: Novoye izdatel'stvo.

Grif sekretnosti snyat. Poteri vooruzhennykh sil SSSR v voynakh, boyevykh deystviyakh i voyennykh konfliktakh [Secrecy label removed. Casualties of the armed forces of the USSR in wars, hostilities and military conflicts] (1993). G.F.Krivosheev, ed. Moscow: Voenizdat.

Il'ina I.P. (1977). Vliyaniye voyn na brachnost' sovetskikh zhenshchin [The impact of war on the Soviet women's marriages] // Brachnost', rozhdayemost', smertnost' v Rossii i v SSSR. [Nuptiality, fertility, mortality in Russia and in the USSR]. A.G. Vishnevsky, ed. Moscow: Statistika. 
Ivanova Ye., Mikheyeva A. (1998). Vnebrachnoye materinstvo v Rossii [Extramarital motherhood in Russia] // Naseleniye i obshchestvo [Population and Society]. №28.

Kharchev A.G. (1979). Brak i sem'ya v SSSR [Marriage and family in the USSR]. Moscow: Mysl'.

Khrushchev N.S. (1961). Pis'mo prem'yer-ministru Shvetsii T. Erlanderu [Letter to the Prime Minister of Sweden T. Erlander] // Mezhdunarodnaya zhizn'. №12.

Polyakov Yu., Zhiromskaya V., Aralovets N. (2004). "Demograficheskoye ekho" voyny ["Demographic echo" of the war] // Voyna i obshchestvo, 1941-1945. Kniga 2 [War and Society, 1941-1945. Vol. 2]. Moscow: Nauka.

Rybakovsky L.L. (2000). Lyudskiye poteri SSSR i Rossii v Velikoy otechestvennoy voyne [Casualties of the USSR and Russia in the Great Patriotic War] // Sotsiologicheskiye issledovaniya [Sociological studies]. №8.

Rybakovsky L.L. (2010). Lyudskiye poteri SSSR i Rossii v Velikoy otechestvennoy voyne [Casualties of the USSR and Russia in the Great Patriotic War]. Moscow: Econ-Inform.

S'yezd KPSS (1962). XXII s'yezd KPSS. 17-31 oktyabrya 1961 goda [XXII Congress of the CPSU. 17-31 October 1961]. T. 2. Moscow: Politizdat.

S'yezd VKP(b) (1939). XVIII Syezd Vsesoyuznoy Kommunisticheskoy partii (bol'shevokov) 10-21 marta 1939 goda. Stenograficheskiy otchet [XVIII Congress of the All-Union Communist Party (of Bolshevics) 10-21 March 1939. Verbatim record]. Moscow: OGIZ.

Stalin J. V. (1978). Report on the Work of the Central Committee to the Eighteenth Congress of the C.P.S.U.(B.) (Delivered March 10, 1939.) // Works, Vol. 14/ Red Star Press Ltd., London, 1978. "Marxists Internet Archive". URL: https://www.marxists.org/reference/archive/stalin/works/1939/03/10.htm

Statistisches Bundesamt (2016), Wiesbaden. Animierte Bevölkerungspyramide. URL: https://www.destatis.de/bevoelkerungspyramide/\#!y=1967\&v=2 (accessed: 22.06.2016).

Sudoplatov P.A. (1997). Spetsoperatsii. Lubyanka i Kreml': 1930-je -1950-je [Special tasks. Lubyanka and the Kremlin: the 1930s - the 1950s]. Moscow: OLMA-PRESS.

Tolts M.S. (2004). Tayny sovetskoy demografii [Secrets of the Soviet demography] // Demoscope Weekly № 171-172 URL: http://www.demoscope.ru/weekly/2004/0171/analit06.php\#00 (accessed: 22.06.2016).

Tolts M.S. (2014). Ot abortnogo termidora k zakonodatel'nomu liberalizmu. Politika v oblasti brachno-semeynykh otnosheniy kak zerkalo istorii SSSR [From abortion Thermidor to the legislative liberalism. The marriage and family relations policy as a mirror of history of the USSR] // Razvitiye naseleniya i demograficheskaya politika [Population development and population policy]. Demograficheskiye issledovaniya. Vyp.23-y. Pamyati A.Ya. Kvashi [Population Studies. Vol.23. In memory of A.Ya. Kvasha]. M.B. Denisenko, V.V. Elizarov, eds. Moscow: MGU.

Tsaplin V.V. (1989). Statistika zhertv stalinizma v 30-ye gody [Statistics of victims of Stalinism in the 30s] // Voprosy istorii, №4.

TSSU SSSR (1975). [Central Statistical Office of the USSR]. Naseleniye SSSR 1973 [The population of the USSR 1973]. Statisticheskiy sbornik [Statistical Yearbook]. Moscow: Statistika.

Ukaz (1944). Ukaz Prezidiuma Verkhovnogo soveta SSSR “Ob uvelichenii gosudarstvennoy pomoshchi beremennym zhenshchinam, mnogodetnym i odinokim materyam, usilenii 
okhrany materinstva i detstva, ob ustanovlenii pochetnogo zvaniya Mat'-geroinya i uchrezhdenii ordena Materinskaya slava i medali Medal' materinstva" [Decree of the Presidium of the Supreme Soviet of the USSR "On the increase of the state help to pregnant women, large families and single mothers, strengthening maternal and child health, the establishment of the honorary title of Mother-Heroine, the Order of Maternal Glory and Medal of motherhood"]. URL: https://www.lawmix.ru/docs_cccp/3096

Vishnevsky A. (1898). Serp i rubl'. Konservativnaya modernizatsiya v SSSR [The sickle and the ruble. Conservative modernization in the USSR]. Moscow: OGI.

Volkov A.G. (2014). Izbrannyye demograficheskiye trudy [Selected demographic works]. Moscow: Izd. dom Vysshey shkoly ekonomiki [HSE Publishing House]

Voznesensky N. (1948). Voyennaya ekonomika SSSR v period Otechestvennoy voyny [The war economy of the USSR during the Patriotic War]. Moscow: Gospolitizdat. 